\title{
Towards ecosystem accounting: a comprehensive approach to modelling multiple hydrological ecosystem services
}

\author{
C. Duku ${ }^{1}$, H. Rathjens ${ }^{2}$, S. J. Zwart ${ }^{3}$, and L. Hein ${ }^{1}$ \\ ${ }^{1}$ Environmental Systems Analysis Group, Wageningen University, P.O. Box 47, 6700AA, Wageningen, the Netherlands \\ ${ }^{2}$ Department of Earth, Atmospheric, and Planetary Sciences, Purdue University, 550 Stadium Mall Drive, \\ West Lafayette, IN 47907-2093, USA \\ ${ }^{3}$ Africa Rice Center, 2031 PB, Cotonou, Benin \\ Correspondence to: C. Duku (confidence.duku@wur.nl, confidence.duku@gmail.com)
}

Received: 20 November 2014 - Published in Hydrol. Earth Syst. Sci. Discuss.: 30 March 2015

Revised: 12 October 2015 - Accepted: 13 October 2015 - Published: 30 October 2015

\begin{abstract}
Ecosystem accounting is an emerging field that aims to provide a consistent approach to analysing environment-economy interactions. One of the specific features of ecosystem accounting is the distinction between the capacity and the flow of ecosystem services. Ecohydrological modelling to support ecosystem accounting requires considering among others physical and mathematical representation of ecohydrological processes, spatial heterogeneity of the ecosystem, temporal resolution, and required model accuracy. This study examines how a spatially explicit ecohydrological model can be used to analyse multiple hydrological ecosystem services in line with the ecosystem accounting framework. We use the Upper Ouémé watershed in Benin as a test case to demonstrate our approach. The Soil Water and Assessment Tool (SWAT), which has been configured with a grid-based landscape discretization and further enhanced to simulate water flow across the discretized landscape units, is used to simulate the ecohydrology of the Upper Ouémé watershed. Indicators consistent with the ecosystem accounting framework are used to map and quantify the capacities and the flows of multiple hydrological ecosystem services based on the model outputs. Biophysical ecosystem accounts are subsequently set up based on the spatial estimates of hydrological ecosystem services. In addition, we conduct trend analysis statistical tests on biophysical ecosystem accounts to identify trends in changes in the capacity of the watershed ecosystems to provide service flows. We show that the integration of hydrological ecosystem services into an ecosystem accounting framework provides relevant information on
\end{abstract}

ecosystems and hydrological ecosystem services at appropriate scales suitable for decision-making.

\section{Introduction}

Ecosystem accounting provides a systematic framework to link ecosystems to economic activities (Boyd and Banzhaf, 2007; Maler et al., 2008; EC et al., 2013; Edens and Hein, 2013; Obst et al., 2013). Specifically, ecosystem accounting aims to integrate the concept of ecosystem services into a national accounting context as described in UN et al. (2009). There is increasing interest in ecosystem accounting as a new, comprehensive tool for environmental monitoring and management (Obst et al., 2013). The recently released System of Environmental-Economic Accounting (SEEA)-Experimental Ecosystem Accounting guideline (EC et al., 2013) provides guidelines for setting up both biophysical and monetary ecosystem accounts. Biophysical accounting for ecosystem services forms the basis for monetary accounting.

Ecosystem services are the contributions of ecosystems to human welfare (TEEB, 2010; EC et al., 2013). Hydrological ecosystem services, specifically, are the contributions to human benefits produced by the effects of terrestrial ecosystem components on freshwater as it moves through the landscape. Terrestrial ecosystem components directly modify different attributes (such as quantity, quality, location and timing) of various ecohydrological processes, resulting in augmentation or degradation of these processes (Brau- 
man et al., 2007). Factors such as the presence of beneficiaries (Boyd and Banzhaf, 2007), spatiotemporal accessibility (Fisher et al., 2009), and management pressure (Schröter et al., 2014) then determine whether the ecohydrological processes constitute hydrological ecosystem services. Hydrological ecosystem services are diverse and can be broadly classified into five categories: improvement of extractive water supply, improvement of in-stream water supply, water damage mitigation, provision of water-related cultural services, and water-associated supporting services (Brauman et al., 2007). Production of these services underlies water and food security and the protection of human lives and properties.

Biophysical accounting for hydrological ecosystem services allows for the organization and analysis of biophysical data on these services at different spatial and temporal scales suitable for the development, monitoring and evaluation of public policy (EC et al., 2013). Biophysical accounting also allows for the distinction between the flow of hydrological ecosystem services and the capacity of watershed ecosystems to provide service flows (EC et al., 2013). Service flow is the contribution in space and time of an ecosystem to either a utility function (e.g. private household) or a production function (e.g. crop production) that leads to a human benefit, whereas service capacity is a reflection of ecosystem condition and extent at a point in time, and the resulting potential to provide service flows (EC et al., 2013; Edens and Hein, 2013). For hydrological ecosystem services, high service capacity areas and high service flow areas may occur in different points or areas in space (Fisher et al., 2009), making the need for their empirical distinction and separate spatial characterization crucial for land and watershed management.

Many approaches have been used for modelling, mapping and quantifying hydrological ecosystem services (e.g. Le Maitre et al., 2007; Naidoo et al., 2008; Liquete et al., 2011; Maes et al., 2012; Notter et al., 2012; Willaarts et al., 2012; Leh et al., 2013; Liu et al., 2013; Terrado et al., 2014, for an overview). For ecosystem accounting, however, key aspects requiring further research include the modelling of hydrological ecosystem services with adequate spatiotemporal detail and accuracy at aggregated scales, distinguishing between service capacity and service flow, and linking ecohydrological processes (and ecosystem components) to the supply of dependent hydrological ecosystem services. Addressing these issues requires the consideration of among others physical and mathematical representation of ecohydrological processes, spatial heterogeneity of ecosystems, temporal resolution, and required model accuracy (Guswa et al., 2014). Adequate representation of the spatial heterogeneity of biophysical environments in ecohydrological models is crucial in ecosystem accounting because spatial units form the basic focus of measurement similar to functions of economic units in national accounting (EC et al., 2013). In addition, if ecosystem accounting is to provide reliable information for the assessment of integrated policy responses at the landscape level, then physical and mathematical representation of model processes should be based on scientific consensus (Vigerstol and Aukema, 2011). Furthermore, model results should be accurate and model uncertainties should be understood and reported (Seppelt et al., 2011; MartínezHarms and Balvanera, 2012). Finally, ecohydrological modelling for ecosystem accounting necessitates the use of continuous simulation watershed models that are able to capture short- and long-term temporal variability in ecohydrological processes.

Our objective is to present a spatially explicit modelling approach aligned with an ecosystem accounting framework to map and quantify the capacities and the flows of multiple hydrological ecosystem services. We use the Soil Water and Assessment Tool (SWAT), which has been configured with a grid-based landscape discretization and further enhanced to simulate water flow across the discretized landscape units, to simulate the watershed ecohydrology. The model is calibrated and validated, and indicators consistent with the ecosystem accounting framework are used to map and quantify the capacities and the flows of multiple hydrological ecosystem services based on the model outputs. Biophysical ecosystem accounts are subsequently set up based on the spatial estimates of hydrological ecosystem services. We use the Upper Ouémé watershed in Benin as a test case to demonstrate our approach. This case-study area was selected because of a relatively high data availability (Judex and Thamm, 2008; AMMA-CATCH, 2014). It is also a microcosm of rural sub-Saharan Africa, where large sections of the population depend on smallholder rainfed agriculture for their livelihood, where groundwater is the major source of drinking water, and where rapid population growth and increasing land use change are prevalent. The hydrological ecosystem services we model and account for are crop water supply, household water supply (groundwater supply and surface water supply), water purification, and soil erosion control. We select these four services because they are critical to food and water security for the population. Agriculture is the major source of income and livelihood in the watershed and is predominantly rainfed. Furthermore, groundwater is the major source of household water use (for both drinking and non-drinking purposes).

\section{Description of the case-study area}

The Upper Ouémé watershed as depicted in Fig. 1 is located in central Benin, covering an area of approximately $14500 \mathrm{~km}^{2}$. The natural vegetation is a mosaic of savannah woodland and small forest islands. The Upper Ouémé forest reserve is the major protected forest area in the watershed, with an approximate area of $2420 \mathrm{~km}^{2}$. Smallholder rainfed agriculture is the major economic activity and is supported by climatic conditions that are characterized by a unimodal rainfall season from May to October of about $1250 \mathrm{~mm}$ per year. 


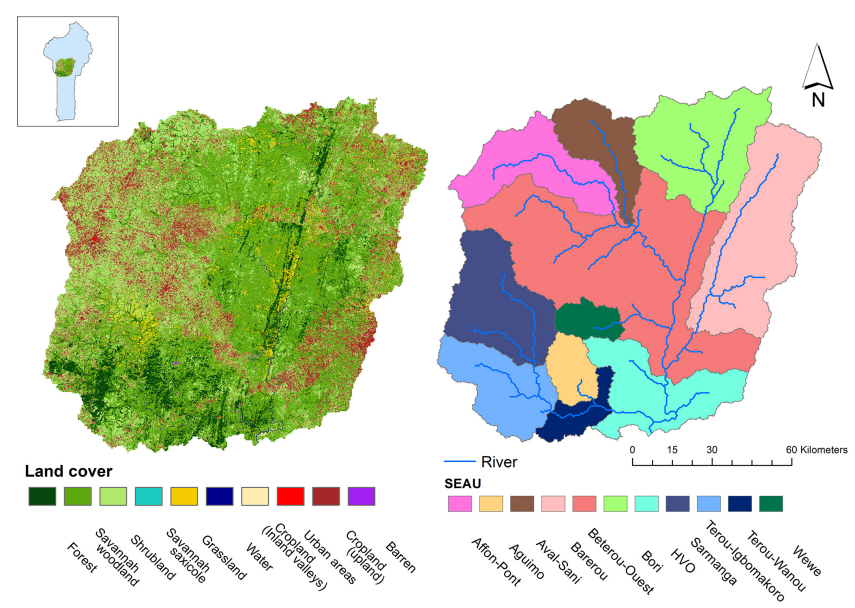

Figure 1. Land cover and subwatershed ecosystem accounting units (SEAUs) of the Upper Ouémé watershed. Land cover data adapted from Judex and Thamm (2008).

Maize, rice, yam, cassava and millet are some of the important food crops cultivated in this area, with cotton being the major cash crop. These crops are predominantly cultivated using rainfed agriculture. The irrigation sector is relatively poorly developed. Rice is mostly cultivated in inland valley lowlands due to their higher water availability, lower soil fragility and higher fertility compared to upland areas (Giertz et al., 2012; Rodenburg et al., 2014). Fertilizer use is increasing in the region and high fertilizer inputs are associated with crops such as maize, rice and cotton (Bossa et al., 2012). An estimated average of $100-250 \mathrm{~kg} \mathrm{ha}^{-1}$ of fertilizer (nitrogen, phosphorus and potassium NPK + urea) is applied to cotton, rice and maize (Bossa et al., 2012). With a population of about 400000 , there is low demographic density (28 inhabitants km${ }^{-2}$ ) in the watershed (Judex and Thamm, 2008). However, the population is growing rapidly (about $4 \% \mathrm{yr}^{-1}$ ) due to migrants coming from different parts of the country and other neighbouring countries to farm. Rapid population growth has caused the expansion of agricultural areas and led to both deforestation and increasing scarcity of agricultural land (Judex and Thamm, 2008) accompanied by increasing soil degradation due to shortening of the fallow period (Giertz et al., 2012). It has been estimated that there will be nearly complete deforestation in some parts of the Upper Ouémé watershed assuming a $6 \% \mathrm{yr}^{-1}$ expansion of agricultural areas (Orekan, 2007). Conversion of savannah woodland and forests for crop cultivation is mainly through slash and burn techniques. In addition, the population obtains about $90 \%$ of its drinking water needs directly from groundwater, with about $5 \%$ from small lakes, ponds and rivers collectively referred to in this study as surface water (Judex and Thamm, 2008).

\section{Methods}

\subsection{Modelling framework}

\subsubsection{Model selection}

In order to address modelling challenges regarding model process inclusion, spatial heterogeneity, physical and mathematical representation, temporal resolution, and model accuracy, we considered several watershed models and selected the SWAT model (Arnold et al., 1998) to be most appropriate for this study. The SWAT model has a comparative advantage in integrated assessment modelling of ecohydrological interactions that underpin hydrological ecosystem services provision (Vigerstol and Aukema, 2011). The SWAT model is a physically based, ecohydrological model that simulates the impact of land use and land management practices on water, sediments and agricultural chemicals in large complex watersheds (Neitsch et al., 2009). It is a continuous simulation watershed model operated at a daily time step. In the SWAT model, a watershed can be spatially discretized using three approaches. They are grid cells, representative hillslopes, and hydrologic response units (HRUs) (Arnold et al., 2013). The HRU-based discretization is the most popular and most geographic information system interfaces are set up to use this discretization (e.g. ArcSWAT). Each HRU is a lumped area within a subwatershed that is comprised of unique land cover, soil and management combinations (Neitsch et al., 2009). The hydrological cycle is divided into two phases. The first is the land phase which controls the amount of water, sediment, nutrient and pesticide loadings to the main channel in each subwatershed. Land phase processes include weather, hydrology (canopy storage, infiltration, evapotranspiration, surface runoff, lateral subsurface flow, return flow) plant growth, erosion, nutrients and management operations (Neitsch et al., 2009). Surface runoff, lateral flow and return flow from the land phase are then routed through the channel network of the watershed to the outlet in the second phase called the routing phase. This phase also includes processes such as sediment and nutrient routing (Neitsch et al., 2009).

\subsubsection{Model modification}

The SWAT model used in this study had two major modifications; the first one was a model process modification, whereas the second one was a modification of the spatial discretization scheme. The process modification involved the incorporation of a landscape routing sub-model that simulates surface water, lateral and groundwater flow interactions across discretized landscape units. This sub-model was developed and incorporated into the standard SWAT model by Volk et al. (2007) and Arnold et al. (2010). The modified model, the SWAT Landscape model, addresses an inherent weakness in the standard SWAT model. The standard SWAT model uses an HRU-based discretization and transported wa- 
ter, sediment, nutrient and pesticide loadings from upstream HRUs are routed directly into stream channels bypassing downstream HRUs (Gassman et al., 2007; Volk et al., 2007; Arnold et al., 2010; Bosch et al., 2010). Therefore, the impact of management of upstream HRUs on downstream HRUs cannot be sufficiently assessed. This weakness is a result of the lack of spatial interactions among different HRUs in the land phase of the hydrological cycle (Neitsch et al., 2009). The SWAT Landscape model addresses this weakness by using a constant flow separation ratio to partition landscape and channel flow in each HRU (Arnold et al., 2010). The channel flow portion is routed through the stream network, whereas the landscape flow portion is routed from upstream HRUs to downstream HRUs.

The second modification was a change from the HRUbased spatial discretization scheme of the standard SWAT model to a grid-based landscape discretization scheme. We set up the SWAT Landscape model with this grid-based landscape discretization using SWATgrid (Rathjens and Oppelt, 2012). The grid-based set-up of the SWAT Landscape model uses a modified topographic index to estimate spatially distributed proportions of landscape and channel flow (Rathjens et al., 2014), unlike the HRU-based set-up which uses a constant flow separation ratio. A new parameter called the drainage density factor controls the spatially distributed flow separation in the SWATgrid set-up (Rathjens et al., 2014). This parameter can be adjusted during calibration. For this study, the grid-based set-up of the SWAT Landscape model was used to delineate the watershed into spatially interacting grid cells. Flow paths were determined from the digital elevation model (DEM) and the TOPAZ digital landscape analysis tool (Garbrecht and Martz, 2000) and runoff from a grid cell flowed to one of eight adjacent cells (Rathjens et al., 2014). A detailed description of the two modifications can be found in Arnold et al. (2010) and Rathjens et al. (2014).

\subsubsection{Model input data}

A combination of spatial and non-spatial input data from a variety of sources was used to set up the model. The spatial input data are described in Table 1. A $30 \mathrm{~m}$ DEM was obtained from the National Aeronautics and Space Administration (NASA) ASTER Global Digital Elevation Map to generate stream networks and watershed configurations, and to estimate topographic parameters. Land cover and soil maps were obtained from the Integrated Approach to Efficient Management of Scarce Water Resources in West Africa (IMPETUS) project database (Judex and Thamm, 2008). The land cover map had been derived from classification of LANDSAT-7 ETM+ satellite images. Gridded daily precipitation data were obtained from the African Monsoon and Multidisciplinary Analysis-Coupling the Tropical Atmosphere and the Hydrological Cycle (AMMA-CATCH) database (AMMA-CATCH, 2014) and gridded temperature data were obtained from the Climate Research Unit (CRU)
TS 3.21 database (Jones and Harris, 2013). Data on groundwater and surface water household consumption (including drinking and non-drinking purposes) were obtained from the IMPETUS project database. These had been derived from national census and household surveys in about 200 towns and communities within the watershed (INSAE, 2003; Hadjer et al., 2005; Judex and Thamm, 2008). For our study area, per capita groundwater consumption was $19 \mathrm{~L}$ per day per person and per capita surface water consumption was $14 \mathrm{~L}$ per day per person (INSAE, 2003; Hadjer et al., 2005).

\subsubsection{Model configuration and performance evaluation}

The initial model set-up was carried out with the ArcSWAT interface, which is based on an HRU configuration. This was essential for generating input data for the grid-based configuration. Simulations of the HRU-based SWAT model were conducted for the period 1999-2012. The first 2 years (1999 and 2000) served as a warm-up period for the model to assume realistic initial conditions. Potential evapotranspiration was modelled with the Hargreaves method (Hargreaves et al., 1985) and water transfers for households were modelled as constant extraction rates from shallow aquifers (groundwater extractions) and streams (surface water extractions). The Soil Conservation Service curve number approach was used to model surface runoff and the daily curve number value was calculated as a function of plant evapotranspiration (Neitsch et al., 2009). The HRU-based SWAT model was first calibrated and validated with streamflow data before calibration and validation of sediment and nitrogen loads. A split-time calibration and validation technique was carried out on the HRU-based model using the Sequential Uncertainty Fitting (SUFI-2) optimization algorithm of the SWAT Calibration and Uncertainty Program (Abbaspour et al., 2008). For calibration and validation of streamflow, we used daily observed streamflow data from 11 monitoring stations within the watershed. These stations had drainage areas of varying spatial scale to capture watershed-scale and subwatershed-scale ecohydrological processes. Calibration was mostly from 2001 to 2007 and validation was from 2008 to 2011. To evaluate transport of sediments and nutrients, the model was further calibrated with weekly measured sediment and organic nitrogen load data. Two years of data (2008-2009) were available from a single monitoring station, Beterou station. Sediment and organic nitrogen load data for 2008 were used for the calibration, whereas data for 2009 were used for the validation.

The calibrated and validated input parameter sets from the HRU-based set-up were transferred to the grid-based set-up of the SWAT Landscape model using the SWATgrid interface (Rathjens and Oppelt, 2012). Given the computational resources and time required to run a grid-based set-up of the SWAT Landscape model at a higher spatial resolution (e.g. 1 ha) for a relatively large watershed such as the Upper Ouémé (Arnold et al., 2010; Rathjens and Oppelt, 2012), we 
Table 1. Description of spatial input data of the Upper Ouémé watershed for the SWAT Landscape model.

\begin{tabular}{llll}
\hline Data type & Description & Resolution & Source \\
\hline $\begin{array}{l}\text { Topography } \\
\text { Land use/land cover }\end{array}$ & ASTER digital elevation model (DEM) & $30 \mathrm{~m}$ & NASA \\
Soil types & $\begin{array}{l}\text { Classified LANDSAT-7 ETM+ image } \\
\text { Soil map and associated parameters derived from } \\
\text { geological maps and field surveys }\end{array}$ & $28.5 \mathrm{~m}$ & IMPETUS \\
$\begin{array}{l}\text { Precipitation } \\
\text { Temperature }\end{array}$ & $\begin{array}{l}\text { Gridded daily precipitation data (1999-2012) } \\
\text { Gridded monthly average minimum and } \\
\text { Household water consumption }\end{array}$ & $25 \mathrm{~km}$ & IMPETUS \\
& Groundwater and surface water extractions & AMM-CATCH \\
(village level) & IMPETUS \\
\hline
\end{tabular}

resampled the DEM, soil and land cover data to a resolution of $500 \mathrm{~m} \times 500 \mathrm{~m}$. The resampling allowed for a balance between computational efficiency during model simulation and maintenance of accurate spatial representation of landscape patterns. Grid-based simulations of the SWAT Landscape model were conducted for the period 1999-2012. The first 2 years served as a model warm-up period. The grid-based set-up of the SWAT Landscape model was then calibrated manually by adjusting only the drainage density factor parameter. The full calibrated parameter values are listed in Table 3. Three quantitative statistics recommended by Moriasi et al. (2007) were selected to evaluate model performance: Nash-Sutcliffe efficiency (NSE), percent bias (PBIAS), and ratio of the root mean square error to the standard deviation of measured data (RSR). Nash-Sutcliffe efficiency is a normalized statistic that determines the relative magnitude of the residual variance compared to the measured data variance (Nash and Sutcliffe, 1970); PBIAS measures the average tendency of the simulated data to be larger or smaller than their observed counterparts (Gupta et al., 1999); RSR standardizes root mean squared error using the observations' standard deviation (Moriasi et al., 2007).

\subsection{Spatial assessment of hydrological ecosystem services}

For each hydrological ecosystem service, two appropriate indicators were selected to model service flow and service capacity. Computations were made for each grid cell enabling the model to reflect spatial differences in service flow and in service capacity. The selected hydrological ecosystem services and their service flow and service capacity indicators are shown in Table 2.

\subsubsection{Crop water supply}

An important hydrological ecosystem service input to crop production in rainfed agricultural systems is the provision of plant available water by ecohydrological processes that affect the soil water balance (Pattanayak and Kramer, 2001; IWMI, 2007; Zang et al., 2012). Crop water stress is a major limitation to crop production in rainfed agricultural systems
(IWMI, 2007). We modelled service flow in croplands, which is referred to in this study as upland agricultural fields, and in inland valley lowlands (Rodenburg et al., 2014). Whereas inland valley lowlands in the study area are predominantly used for rice cultivation, the land cover input data did not differentiate the types of crops grown in upland agricultural fields. For our simulations we assumed that all upland agricultural fields were used for only maize cultivation (which is the most common crop in our study area in terms of extent of cultivated land area). For maize cultivation, the growing period (GP), i.e. the time period between crop establishment and harvesting, was 103 days, whereas the GP for rice cultivation was 123 days. For both maize and rice, crop establishment was in the month of June. Service flow of crop water supply was modelled as the total number of days during a growing period in which there was no water stress (i.e. days when the total plant water uptake was sufficient to meet maximum plant water demand). Service flow depends on the specific type of crop cultivated. This approach is based on the model output variable, daily water stress, and is a modification of Notter et al. (2012). For each day, the model used Eq. (1) to compute water stress for a given grid cell, $j$ (Neitsch et al., 2009). After model simulation, service flow was computed using Eq. (2).

$W_{\text {strs, }, j}=1-T_{\text {act, }, j} / T_{\max , j}$,

where $W_{\text {strs }}$ is daily water stress, $T_{\text {act }}$ is plant water uptake or actual transpiration $(\mathrm{mm})$, and $T_{\max }$ is maximum plant water demand or maximum transpiration $(\mathrm{mm})$ :

$S_{\mathrm{f}, j}=N\left(d_{1}, d_{2}, \ldots, d_{n} \mid W_{\text {strs }}=0\right)_{j}$,

where $S_{\mathrm{f}}$ is the service flow (days $\mathrm{GP}^{-1}$ ), and $N$ is the number of days $d_{1}$ to $d_{n}$ when $W_{\text {strs }}$ was zero.

Service capacity on the other hand was modelled as the total number of days in a year when the sum of actual evapotranspiration and the amount of residual moisture added to the soil profile equalled or exceeded potential evapotranspiration. For a given spatial unit, this gives an indication of the number of days when potentially there will be no crop water stress irrespective of the crop type to be cultivated. This approach has management relevance. Our approach was 
Table 2. Overview of selected hydrological ecosystem services and associated service flow and service capacity indicators (GP is growing period).

\begin{tabular}{|c|c|c|}
\hline Hydrological ecosystem service & Service flow indicator & Service capacity indicator \\
\hline 1. Crop water supply & $\begin{array}{l}\text { Total number of days during the growing } \\
\text { period in which there was no water stress } \\
\left(\text { days } \mathrm{GP}^{-1}\right)\end{array}$ & 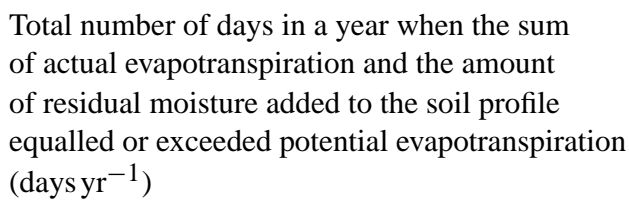 \\
\hline $\begin{array}{l}\text { 2. Household water supply } \\
\text { a. Groundwater supply }\end{array}$ & $\begin{array}{l}\text { Amount of groundwater extracted } \\
\left(\mathrm{m}^{3} \mathrm{ha}^{-1} \mathrm{yr}^{-1}\right)\end{array}$ & $\begin{array}{l}\text { Groundwater recharge } \\
\left(\mathrm{m}^{3} \mathrm{ha}^{-1} \mathrm{yr}^{-1}\right)\end{array}$ \\
\hline b. Surface water supply & $\begin{array}{l}\text { Amount of surface water extracted } \\
\left(\mathrm{m}^{3} \mathrm{ha}^{-1} \mathrm{yr}^{-1}\right)\end{array}$ & $\begin{array}{l}\text { Water yield } \\
\left(\mathrm{m}^{3} \mathrm{ha}^{-1} \mathrm{yr}^{-1}\right)\end{array}$ \\
\hline Water purification & $\begin{array}{l}\text { Rate of denitrification } \\
\left(\mathrm{kg} \mathrm{ha}^{-1} \mathrm{yr}^{-1}\right)\end{array}$ & $\begin{array}{l}\text { Denitrification efficiency } \\
\text { (\% denitrified) }\end{array}$ \\
\hline 4. Soil erosion control & $\begin{array}{l}\text { Reduction in soil loss } \\
\left.\text { (metric tha }{ }^{-1} \mathrm{yr}^{-1}\right)\end{array}$ & $\begin{array}{l}\text { Maximum potential reduction in soil loss } \\
\left(\text { metric tha } \mathrm{hr}^{-1} \mathrm{yr}^{-1}\right)\end{array}$ \\
\hline
\end{tabular}

Table 3. Description of calibrated parameter values of the SWAT Landscape model. Superscript a indicates that the fitted values depended on the land cover type. Superscript $b$ indicates that this parameter was used only in the calibration of the grid-based SWAT Landscape model. Subscript $v_{-}$indicates that the parameter value is replaced by the fitted value. Subscript $r_{-}$indicates the parameter value is multiplied by $(1+$ the fitted value).

\begin{tabular}{lll}
\hline Parameter name & Description & Fitted values \\
\hline r_CN2 & Initial SCS (Soil Conservation Service) runoff curve number for moisture condition II & ${\text { (From }-0.2 \text { to }-0.05)^{\mathrm{a}}}^{\mathrm{a}}$ \\
v_RCHRG_DP & Deep aquifer percolation fraction & 0.2 \\
v_GW_REVAP & Groundwater re-evaporation coefficient & 0.18 \\
v_GWQMN & Threshold depth of water in the shallow aquifer required for return flow to occur & 1000 \\
v_REVAPMN & Threshold depth of water in the shallow aquifer & 500 \\
& for re-evaporation or percolation to the deep aquifer to occur & 0.12 \\
v_SURLAG & Surface runoff lag coefficient & 0.1 \\
r_SOL_AWC & Available water capacity of the soil & $(\text { From } 0.001 \text { to } 0.2)^{\mathrm{a}}$ \\
v_ESCO & Soil evaporation compensation factor & $(\text { From } 0.1 \text { to } 1)^{\mathrm{a}}$ \\
v_EPCO & Plant uptake compensation factor & 0.13 \\
v_USLE_P & USLE (Universal Soil Loss Equation) support practice factor & $($ From 0.038 to 0.45) \\
v_USLE_C & Minimum value of the USLE C factor for water erosion applicable to the land cover \\
v_NPERCO & Nitrate percolation coefficient & 0.2 \\
v_N_UPDIS & Nitrogen uptake distribution parameter & 70 \\
v_SDNCO & Denitrification threshold water content & 1.1 \\
v_CDN & Denitrification exponential rate coefficient & 1.4 \\
v_DD & Drainage density factor which affects the flow separation ratio & 7.5
\end{tabular}

based on the commonly used method (FAO, 1978, 1983) for determining the length of growing periods in rainfed agricultural systems. Unlike that method where moisture supply was based on precipitation, moisture supply in our approach was based on simulated spatiotemporal soil moisture dynamics. We used this approach for our study because at the local scale terrestrial ecosystem components have very little effect on precipitation attributes such as quantity, location, timing, etc. For a given day, the SWAT model used Eq. (3) to com- pute water balance. From the water balance components we computed the total available soil moisture and subsequently calculated potential water stress using Eq. (4). Service capacity of crop water supply was then computed using Eq. (5).

$$
\Delta \mathrm{SW}_{i}=\sum_{i=1}^{n}\left(R_{\text {day }}-Q_{\text {surf }}-\mathrm{ET}_{\mathrm{a}}-W_{\text {seep }}-Q_{\mathrm{gw}}\right),
$$

where $\Delta \mathrm{SW}$ is the amount of residual moisture added to the soil profile on day $i(\mathrm{~mm}) ; n$ is number of days in the 
year; $R_{\text {day }}$ is the amount of precipitation $(\mathrm{mm}) ; Q_{\text {surf }}$ is the amount of surface runoff $(\mathrm{mm}) ; \mathrm{ET}_{\mathrm{a}}$ is actual evapotranspiration $(\mathrm{mm}) ; W_{\text {seep }}$ is percolation exiting the soil profile $(\mathrm{mm})$; and $Q_{\mathrm{gw}}$ is return flow (mm).

$W_{\mathrm{pstrs}}=1-\left[\left(\Delta \mathrm{SW}+\mathrm{ET}_{\mathrm{a}}\right) / \mathrm{ET}_{\mathrm{p}}\right]$ if $\Delta \mathrm{SW}>0$.

$W_{\text {pstrs }}$ is potential daily water stress; $\Delta \mathrm{SW}$ is the amount of residual moisture added to the soil profile $(\mathrm{mm}) ; \mathrm{ET}_{\mathrm{a}}$ is actual evapotranspiration $(\mathrm{mm}) ; \mathrm{ET}_{\mathrm{p}}$ is potential evapotranspiration (mm).

$S_{\mathrm{c}}=N\left(d_{1}, d_{2}, \ldots, d_{n} \mid W_{\mathrm{pstrs}} \leq 0\right)$,

where $S_{\mathrm{c}}$ is service capacity (days $\mathrm{yr}^{-1}$ ), and $N$ is the number of days $d_{1}$ to $d_{n}$ in a year when potentially there will be no water stress.

\subsubsection{Household water supply}

This hydrological ecosystem service refers to the amount of water extracted before treatment for household consumption (drinking and non-drinking purposes) (EC et al., 2013). This measurement boundary excluded other sources of water (e.g. tap water) where economic agents or inputs (e.g. water treatment facilities) were used to modify the state of the water resources before household consumption. We acknowledge that inflows to reservoirs of water distribution and processing facilities that deliver tap water can be considered as a hydrological ecosystem service. However, we excluded this from our study. This is because in our study area, the population obtain about $90 \%$ of their drinking water needs from groundwater, with about $5 \%$ from small lakes, ponds and rivers collectively referred to in this study as surface water (Judex and Thamm, 2008). A distinction was made between service capacity and service flow from groundwater, and service capacity and service flow from surface water.

To model service flow from groundwater and surface water, data on water consumption per capita, village population and water access for about 200 communities within the watershed were used. These data had been extracted from the 2002 national census (INSAE, 2003) and from household surveys in the study area (Hadjer et al., 2005). The data represented household water consumption (including drinking and non-drinking purposes) and lacked information on the actual points of extraction. Therefore, in modelling the service flow, we assumed that there is a positive spatial correlation between points of consumption and points of extraction. Furthermore, to estimate the village population from 2003 to 2012, we applied a $4 \% \mathrm{yr}^{-1}$ growth rate (Judex and Thamm, 2008). Water consumption per capita, however, was kept constant. A population density grid was created using the ArcGIS kernel density function (ESRI, 2012) and multiplied by water consumption per capita to estimate the amount of water consumed per grid cell. The amount consumed per grid cell then gives an indication of the amount extracted per grid cell.
The ecosystem's capacity to support groundwater extractions was modelled as groundwater recharge, which is the total amount of water entering the aquifers within a specified time step (e.g. month or year) (Arnold et al., 2013). The ecosystem's capacity to support surface water extractions, however, was modelled as the water yield. Water yield is the net amount of water contributed by a grid cell to the river network within a specified time step (Arnold et al., 2013). Both groundwater recharge and water yield are model output variables.

\subsubsection{Water purification}

In the Upper Ouémé watershed, fertilizer application is increasing and high fertilizer input is associated with crops such as maize, rice and cotton (Bossa et al., 2012). Increasing fertilizer application can lead to contamination of groundwater and surface water resources through nutrient leaching. This poses serious environmental and health risks to beneficiaries of these systems (Tilman et al., 2002; Wolfe and Patz, 2002). In our study area, groundwater provides over $90 \%$ of the total household water consumption. Water purification is, therefore, an essential ecosystem service in the Upper Ouémé watershed that increases the quality of groundwater for human consumption as well as other purposes. One of the challenges in terms of quantifying hydrological ecosystem services is the identification of management relevant indicators that can be enhanced through management interventions to augment the service production. For this study, we used soil denitrification as an indicator of this hydrological ecosystem service. Soil denitrification controls the rate of nitrate leaching by determining the quantities (after plant uptake) of nitrate available for leaching into groundwater systems (Jahangir et al., 2012). For example, Kramer et al. (2006) observed that organic farming supports more active and efficient denitrifier communities, leading to a considerable reduction in nitrate leaching as compared to conventional farming. In this study, the SWAT Landscape model was used to simulate the complete nitrogen cycle and service flow was estimated directly as the rate of denitrification, a model output variable. We should emphasize that the SWAT Landscape model does not explicitly simulate microbial processes and dynamics, but rather that it simulates the ecohydrological conditions suitable for denitrification to occur (Boyer et al., 2006). The model, therefore, computes denitrification as a function of soil moisture content, soil temperature, presence of a carbon source and nitrate availability using Eqs. (6) and (7) (Neitsch et al., 2009).

$$
\begin{aligned}
& N_{\mathrm{dn}}=\mathrm{NO}_{3} \cdot\left(1-\exp \left[-\beta_{\mathrm{dn}} \cdot \gamma_{\mathrm{tmp}} \cdot C_{\mathrm{org}}\right]\right) \text { if } \gamma_{\mathrm{sw}} \geq \gamma_{\mathrm{sw}, \mathrm{thr}} \text {, } \\
& N_{\mathrm{dn}}=0 \quad \text { if } \gamma_{\mathrm{sw}}<\gamma_{\mathrm{sw}, \mathrm{thr}} \text {, }
\end{aligned}
$$

where $N_{\mathrm{dn}}$ is the amount of nitrogen lost through denitrification $\left(\mathrm{kgha}^{-1}\right), \mathrm{NO}_{3}$ is the amount of nitrate in the soil $\left(\mathrm{kgha}^{-1}\right), \beta_{\mathrm{dn}}$ is the rate coefficient for denitrification, $\gamma_{\mathrm{tmp}}$ 
is the nutrient cycling temperature factor, $\gamma_{\mathrm{sw}}$ is the nutrient cycling water factor, $\gamma_{\mathrm{sw}, \mathrm{thr}}$ is the threshold value of the nutrient cycling water factor for denitrification to occur, and $C_{\text {org }}$ is the amount of organic carbon (\%). The values of $\beta_{\mathrm{dn}}$ and $\gamma_{\mathrm{sw}, \text { thr }}$ are user-defined values and were adjusted during calibration; $\beta_{\mathrm{dn}}$ was 1.4 and $\gamma_{\mathrm{sw}, \text { thr }}$ was 1.1.

Service capacity was estimated as the denitrification efficiency, which in this study was computed using Eq. (8). When the ecohydrological conditions required for denitrification are present, the rate of denitrification (service flow) is determined by the amount of nitrate available in the soil. Unlike other land cover types (which only receive nitrogen or nitrates from wet deposition or from overland flow), cropland areas receive additional nitrogen or nitrates through fertilizer application. Therefore, for a given grid cell, denitrification efficiency determines the proportion of the total nitrate that is denitrified. As a measure of service capacity, denitrification efficiency gives an indication of the suitability of a spatial unit for denitrification.

$\mathrm{DN}_{\text {eff }}=\left(N_{\mathrm{dn}} / N_{\text {total }}\right) \cdot 100$,

where $\mathrm{DN}_{\text {eff }}$ is the denitrification efficiency $(\%), N_{\mathrm{dn}}$ is the amount of nitrogen lost through denitrification in the time step $\left(\mathrm{kg} \mathrm{ha}^{-1}\right)$, and $N_{\text {total }}$ is the total amount of nitrogen available (e.g. through fertilizer application, wet deposition, etc.) in the time step $\left(\mathrm{kg} \mathrm{ha}^{-1}\right)$.

\subsubsection{Soil erosion control}

Controlling soil erosion in the watershed has numerous benefits including maintaining soil fertility, preventing river sedimentation, and downstream water quality. There are inherent physical soil and landscape properties such as soil erodibility and slope that affect soil erosion (Williams, 1975). However, we focussed on the role of vegetation cover in controlling soil erosion. Service flow was modelled as the actual reduction in soil loss produced by the existing vegetation cover, and was computed using Eq. (9).

$\mathrm{SD}_{\mathrm{rtd}}=S_{\mathrm{yld}, \text { pot }}-S_{\mathrm{yld}}$,

where $\mathrm{SD}_{\mathrm{rtd}}$ is the reduction in soil loss produced by the existing vegetation cover (metrictha ${ }^{-1}$ ), $S_{\text {yld, pot }}$ is the maximum potential soil loss in the absence of vegetation cover (metric tha ${ }^{-1}$ ), and $S_{\text {yld }}$ is the soil loss under prevailing vegetation cover and land management practices (metric tha ${ }^{-1}$ ). Both $S_{\text {yld, pot }}$ and $S_{\text {yld }}$ were computed with the modified universal soil loss equation (Williams, 1975) incorporated into the SWAT Landscape model.

For the service capacity of soil erosion control, we used the maximum potential reduction in soil loss produced by the vegetation cover as an indicator. This maximum potential reduction in soil loss (maximum potential soil retention) can be said to be equal to the maximum potential soil loss. For example, for a specified spatial unit, if the maximum potential soil loss in the absence of the vegetation cover is estimated as 2 metric tha ${ }^{-1} \mathrm{yr}^{-1}$, then it indicates that the potential reduction in soil loss due to the vegetation cover cannot be greater than 2 metric tha ${ }^{-1} \mathrm{yr}^{-1}$. The maximum potential soil loss was modelled assuming there was no vegetation cover (e.g. Leh et al., 2013; Terrado et al., 2014).

\subsection{Accounting for hydrological ecosystem services}

Biophysical ecosystem accounts are the basis for monetary accounting and were set up in accordance with SEEA-Experimental Ecosystem Accounting guidelines (EC et al., 2013). We defined 11 subwatershed ecosystem accounting units (SEAUs) as the spatial scales of aggregation. We set up annual biophysical service capacity and service flow accounts for each SEAU. The 11 SEAUs were defined from a total of 44 subwatersheds based on the drainage areas of streamflow monitoring stations within the watershed. The monitoring stations are listed in Table 4 . The 44 subwatersheds were delineated from the ASTER Global Digital Elevation Map as part of the initial model set-up with ArcSWAT. Some monitoring stations with smaller drainage areas were nested within those with larger drainage areas. In such cases the SEAU was defined as the drainage area of the nested monitoring station because we wanted to set up spatially disaggregated accounts. Large drainage areas of other monitoring stations had nested subwatersheds within them that were ungauged. In these cases also, the SEAU was defined as the nested subwatershed. For each SEAU, the spatial estimates of service capacity load per grid cell $(500 \mathrm{~m} \times 500 \mathrm{~m})$ and service flow load per grid cell $(500 \mathrm{~m} \times 500 \mathrm{~m})$ that had been computed in Sect. 3.2 were then aggregated.

A key motivation for ecosystem accounting is to provide information for tracking changes in ecosystems and linking those changes to economic and other human activities (EC et al., 2013). Trend analysis statistical tests were conducted on the total annual values (or total seasonal values for crop water supply) of service capacity accounts in each SEAU. Trend analysis determines whether the changes in service capacity over time are due to random variability or statistically significant and consistent changes. This was conducted using the non-parametric Mann-Kendall test for trend. The MannKendall test for trend statistically determines whether there is a monotonic upward or downward trend of a variable over time. A trend was detected if temporal variation in service capacity was statistically significant at the $5 \%$ significance level $(P$ value $<0.05)$. If a trend was detected, the MannKendall statistic and Sen's slope estimator were calculated. The Mann-Kendall statistic is a measure of the strength and direction of a trend, whereas Sen's slope estimator is a measure of the magnitude of a trend. 

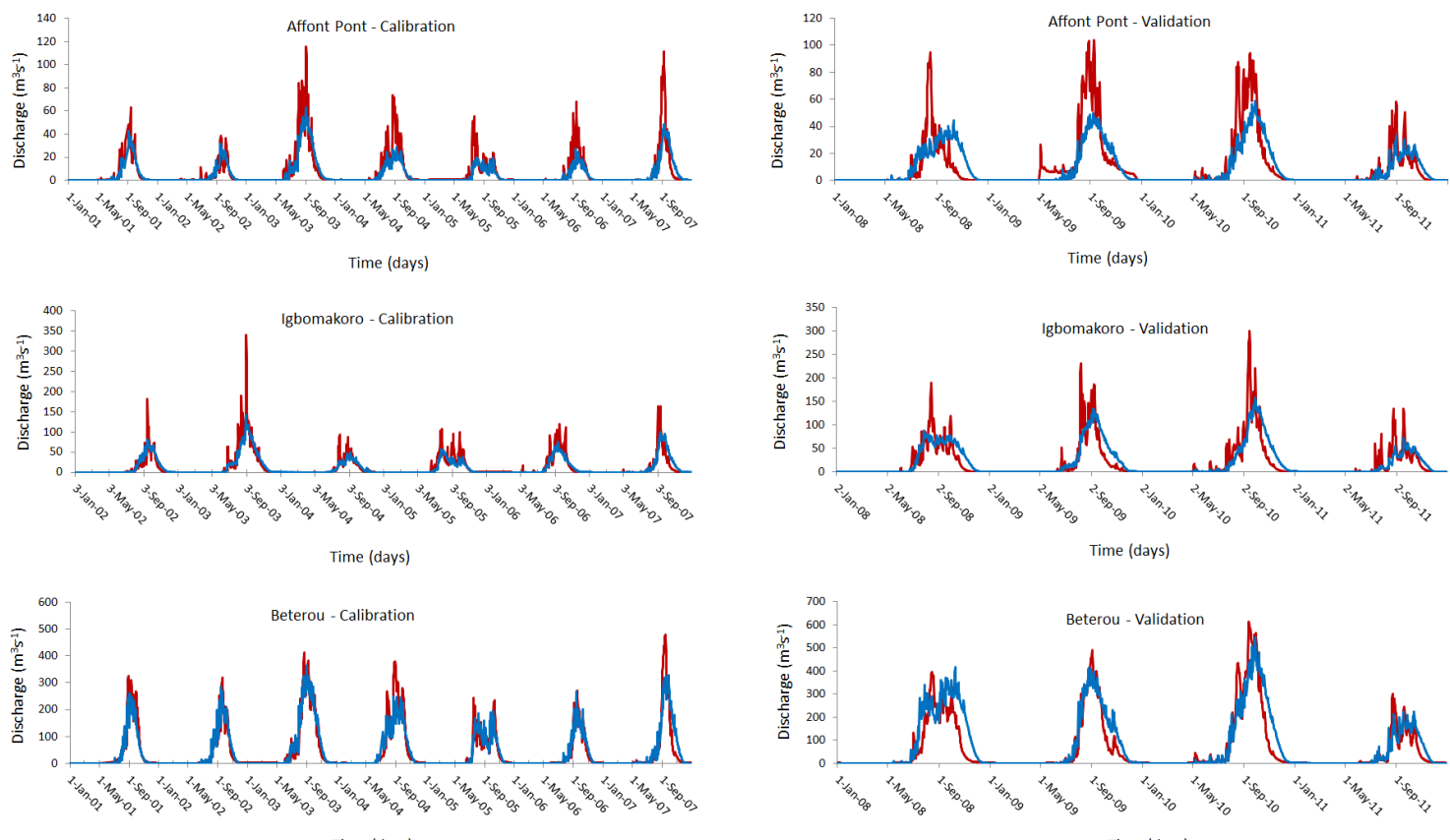

-Observed -Simulated

Figure 2. Comparing simulated and observed streamflow for three monitoring stations with varying drainage areas: Affont-Pont, $1172 \mathrm{~km}{ }^{2}$; Igbomakoro, $2309 \mathrm{~km}^{2}$; Beterou, $10046 \mathrm{~km}^{2}$.
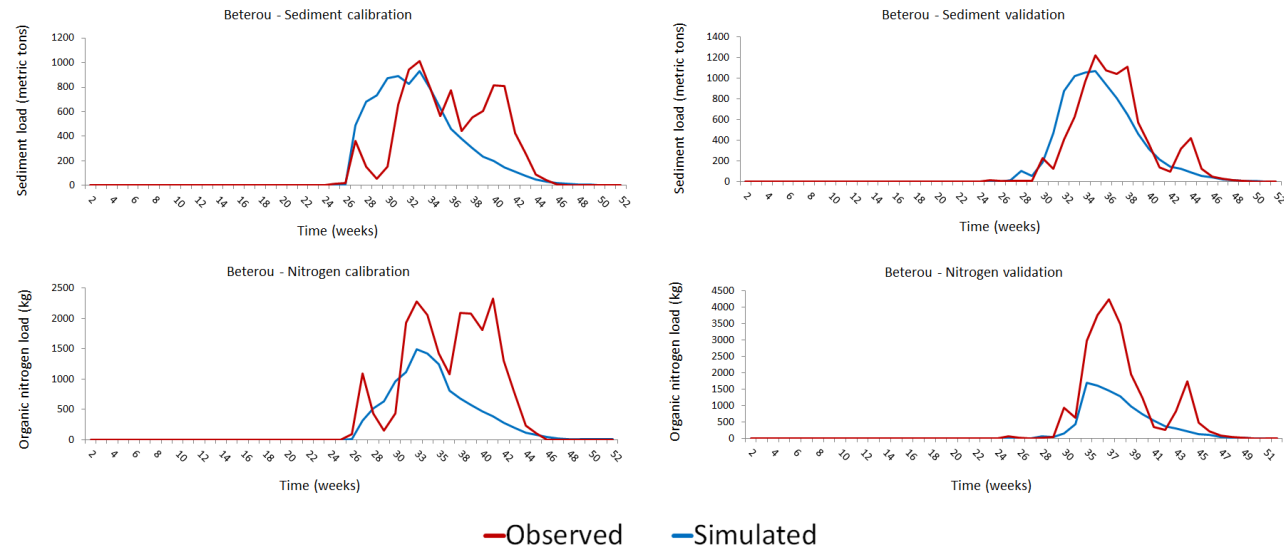

Figure 3. Comparing simulated and observed sediment loads and organic nitrogen loads during calibration and validation at Beterou monitoring station for the period 2008-2009.

\section{Results}

\subsection{SWAT Landscape model calibration and validation results}

Table 4 shows the statistical results of the model calibration and validation and Figs. 2 and 3 show the graphical results. There are no established absolute criteria for judging model performance. For this study, we used the criteria recommended by Moriasi et al. (2007). A watershed model is said to be performing satisfactorily if NSE $>0.50$ and
RSR $<0.70$, PBIAS within the range -25 to 25 for streamflow, -55 to 55 for sediment, and -70 to 70 for nutrients. At different spatial scales (e.g. Affont-Pont, $1172 \mathrm{~km}^{2}$; Igbomakoro, $2309 \mathrm{~km}^{2}$; Beterou, $10046 \mathrm{~km}^{2}$ ), the model simulated hydrological processes satisfactorily as shown in Fig. 2. Seven out of 11 stations recorded NSE values greater than 0.5 during model validation of streamflow. Even though the NSE values for some monitoring stations were less than 0.5 , all but one were greater than 0.0 , indicating that the simulated streamflow was still a better predictor than the mean of 
Table 4. Calibration and validation results for streamflow, sediment and organic nitrogen loads (Prefix $\mathrm{H} \_$indicates results for streamflow calibration and validation; prefix $\mathrm{S}_{\text {_ }}$ indicates results for sediment load calibration; $\mathrm{N}_{\text {_ }}$ indicates results for organic nitrogen load calibration). NSE is Nash-Sutcliffe efficiency, PBIAS is percent bias, and RSR is the ratio of the root mean square error to the standard deviation of measured data.

\begin{tabular}{|c|c|c|c|c|c|c|c|}
\hline \multirow[t]{2}{*}{ Monitoring stations } & \multirow{2}{*}{$\begin{array}{r}\text { Drainage area } \\
\left(\mathrm{km}^{2}\right)\end{array}$} & \multicolumn{3}{|c|}{ Calibration } & \multicolumn{3}{|c|}{ Validation } \\
\hline & & NSE & PBIAS & RSR & NSE & PBIAS & RSR \\
\hline \multicolumn{8}{|l|}{ Upstream stations } \\
\hline H_Affon-Pont & 1172 & 0.69 & 27.0 & 0.56 & 0.62 & 15.9 & 0.62 \\
\hline H_Aval-Sani & 760 & 0.70 & 12.0 & 0.55 & 0.64 & 7.8 & 0.60 \\
\hline H_Bori & 1608 & 0.65 & -24.7 & 0.59 & -0.49 & -121.4 & 1.22 \\
\hline H__Tebou & 522 & 0.47 & 43.5 & 0.72 & 0.58 & 20.3 & 0.65 \\
\hline \multicolumn{8}{|l|}{ Downstream stations } \\
\hline H__Beterou & 10046 & 0.85 & 5.7 & 0.39 & 0.78 & -17.8 & 0.47 \\
\hline H__Barerou & 2128 & 0.71 & 20.8 & 0.54 & 0.72 & -22.7 & 0.53 \\
\hline H_Cote- 238 & 3040 & 0.69 & 3.5 & 0.56 & 0.68 & -18.4 & 0.56 \\
\hline H_Igbomakoro & 2309 & 0.76 & 11.3 & 0.49 & 0.71 & -4.0 & 0.54 \\
\hline $\mathrm{H} \_$Sarmanga & 1334 & 0.48 & 23.2 & 0.72 & 0.44 & 17.2 & 0.75 \\
\hline H_Aguimo & 394 & 0.25 & -20.9 & 0.87 & 0.12 & -60.1 & 0.94 \\
\hline H__Wewe & 297 & 0.42 & 21.6 & 0.76 & 0.42 & -6.5 & 0.76 \\
\hline $\mathrm{S} \_$Beterou & 10046 & 0.45 & 6.9 & 0.74 & 0.83 & 2.55 & 0.42 \\
\hline $\mathrm{N}_{\text {_B Beterou }}$ & 10046 & 0.50 & 47.4 & 0.71 & 0.55 & 56.3 & 0.67 \\
\hline
\end{tabular}

the observed values. Monitoring stations with larger drainage areas recorded higher NSE values than stations with smaller drainage areas. The PBIAS values in Table 4 show the level of bias in simulated streamflow. A negative PBIAS value indicates model overestimation, whereas a positive PBIAS value indicates model underestimation. The validation results show that the model largely underestimated streamflow at upstream stations and overestimated it downstream. The RSR results show varying levels of residual variation indicating the level of errors in simulated streamflow as compared to observed streamflow. The closer the RSR value is to zero, the lower the level of residual variation in simulated streamflow. During model validation, five stations recorded RSR values lower than 0.7 . For sediment and nitrogen transport processes, the model performed satisfactorily. The statistical and graphical results of sediment load and organic nitrogen load during calibration and validation are shown in Fig. 3 and Table 4.

\subsection{Spatial patterns of hydrological ecosystem services}

Water supply by soil moisture is essential to reduce crop water stress in rainfed agricultural systems. If all other factors for crop growth (such as nutrients and temperature) remain constant, then a higher service capacity and higher service flow result in a higher crop yield. Computations of crop water supply were spatially restricted to upland agricultural fields. High service flow indicates the suitability of a spatial unit under assumed maize cultivation, whereas high service ca- pacity indicates the potential suitability for crop cultivation irrespective of the crop type and not maize alone. The results of service capacity are indicative of the least number of days during a year crops would not experience water stress. Figure 4 reveals high spatial variability in service capacity and service flow in upland agricultural fields. Mean annual values of service capacity in upland agricultural fields ranged

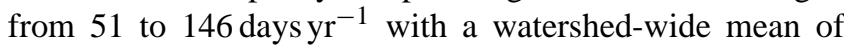
93 days $\mathrm{yr}^{-1}$ and standard deviation of 24 days $\mathrm{yr}^{-1}$. The spatial distribution of mean annual values of service capacity and service flow in inland valley rice fields are not shown because of their significantly low total area (less than $1 \%$ of the total cropland area). Mean annual values of service ca-

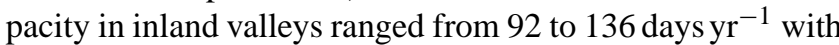
a watershed-wide mean of 124 days $\mathrm{yr}^{-1}$ and standard deviation of 9 days $\mathrm{yr}^{-1}$. Mean seasonal values of service flow in inland valleys ranged from 67 to 123 days $\mathrm{GP}^{-1}$ with a watershed-wide mean of 117 days $\mathrm{GP}^{-1}$ and a standard deviation of 12 days $\mathrm{GP}^{-1}$. Overall, more than $95 \%$ (approximately $1050 \mathrm{ha}$ ) of inland valley rice fields recorded mean seasonal values of service flow of at least 90 days, whereas less than $25 \%$ (approximately $36000 \mathrm{ha}$ ) of upland agricultural areas recorded mean seasonal values of service flow of at least 90 days.

The spatial distribution of mean annual values of service capacity and service flow of groundwater supply and surface water supply are shown in Figs. 5 and 6 respectively. Groundwater is the major source of water for household consumption (drinking and non-drinking purposes), with the service 


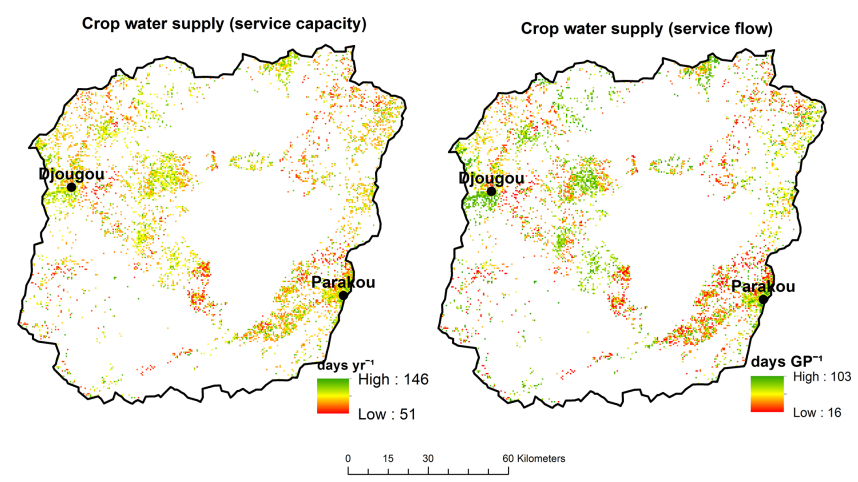

Figure 4. Spatial distribution of mean annual values of service capacity and mean seasonal values of service flow of crop water supply in upland agricultural areas in the Upper Ouémé watershed from 2001 to 2012 (GP indicates growing period).

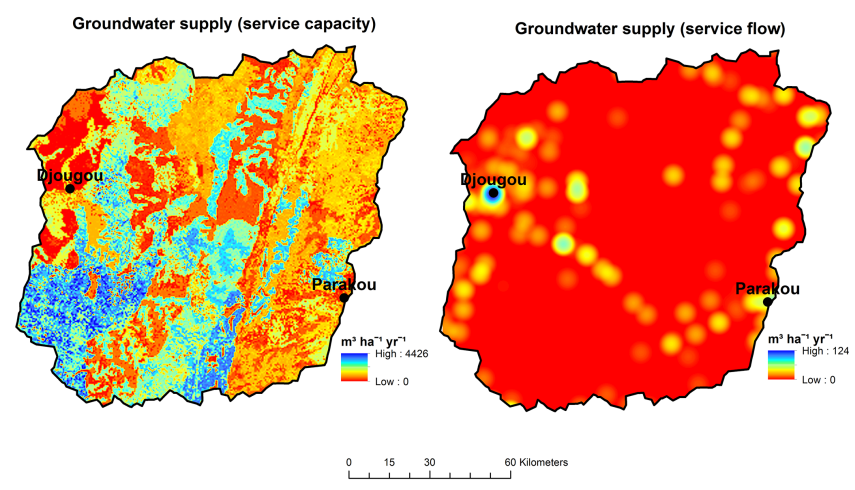

Figure 5. Spatial distribution of mean annual values of service capacity and service flow of groundwater supply in the Upper Ouémé watershed from 2001 to 2012.

flow (groundwater extraction) significantly higher than the service flow of surface water supply (surface water extraction). High service flows of groundwater supply are concentrated in the most populous towns in the watershed. However, service flows in Parakou, which is the most populous city in the watershed, are relatively lower than in other areas such as Djougou. This is because the population in Parakou depends mainly on tap water sources. Service capacity of groundwater supply exhibited high spatial variability. High values of service capacity were concentrated in the south-western part of the watershed. For service capacity of surface water supply, Fig. 6 shows areas with a high propensity for generating water yield. These areas, referred to as hydrologically sensitive areas (HSAs) (Agnew et al., 2006), were not peculiar to a particular land cover type. They occurred in almost all land cover types. They occurred more frequently in savannah woodland and shrubland because approximately $80 \%$ of the total watershed area is either one of this land cover type.

Water purification modelled as denitrification is essential to control the quantities of nitrate available for leaching and contaminating groundwater resources (Jarvis, 2000; Jahangir

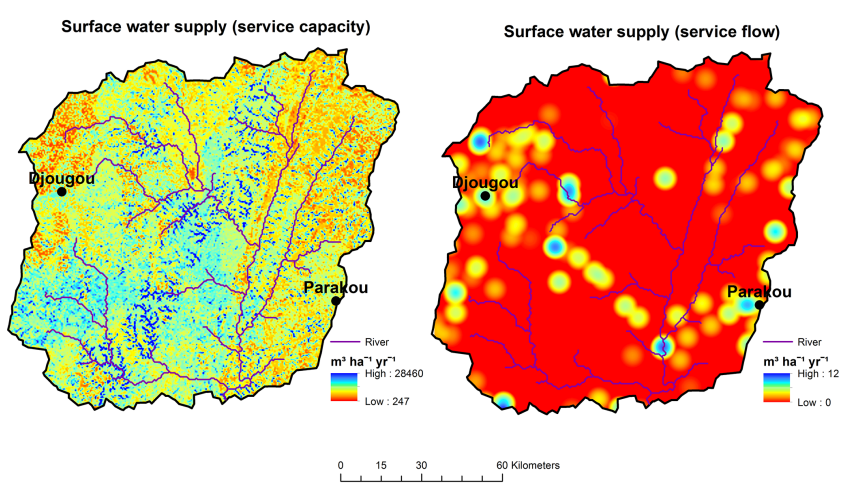

Figure 6. Spatial distribution of mean annual values of service capacity and service flow of surface water supply in the Upper Ouémé watershed from 2001 to 2012.

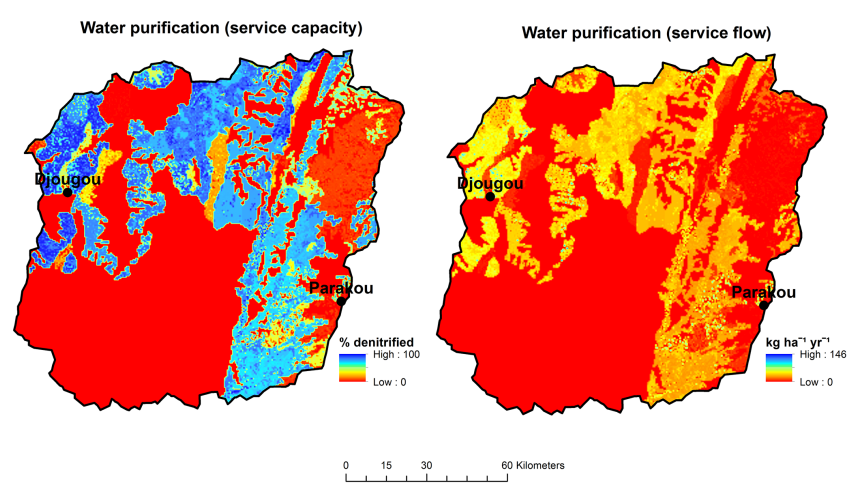

Figure 7. Spatial distribution of mean annual values of service capacity and service flow of water purification in the Upper Ouémé watershed from 2001 to 2012.

et al., 2012). Service capacity was measured as the percentage of nitrate that is denitrified and service flow was the rate of denitrification. The spatial distribution of mean annual values of service capacity and service flow of water purification are distinctly concentrated in the northern and eastern parts of the watershed, with the south-western parts recording zero values (Fig. 7). All barren land cover types also recorded zero values of service capacity and service flow. The zero values recorded are a result of the lack of soil saturation conditions and not the lack of nitrate availability. Soil saturation induces soil anaerobic conditions required for denitrification to take place. In areas where denitrification was recorded, the highest mean annual values of service flow were recorded in inland valley rice fields $\left(12 \mathrm{kgha}^{-1} \mathrm{yr}^{-1}\right)$ and grasslands $\left(7 \mathrm{~kg} \mathrm{ha}^{-1} \mathrm{yr}^{-1}\right)$. The highest mean annual values of service capacity were also recorded in grasslands $\left(55 \% \mathrm{yr}^{-1}\right.$ and inland valley rice fields $\left(35 \% \mathrm{yr}^{-1}\right)$.

The spatial distributions of mean annual values of service capacity and service flow of soil erosion control are shown in Fig. 8. High service capacity indicates high potential for reduction in soil loss produced by the vegetation cover. The service flow, however, is a measure of the actual 


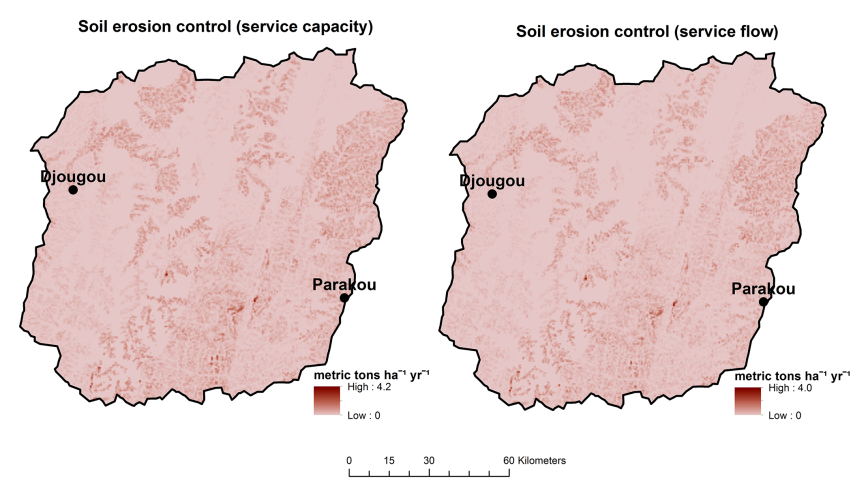

Figure 8. Spatial distribution of mean annual values of service capacity and service flow of soil erosion control in the Upper Ouémé watershed from 2001 to 2012.

reduction in soil loss under existing vegetation cover. Under existing vegetation cover, the mean annual rate of soil loss in the watershed was recorded at 0.01 metric tha ${ }^{-1} \mathrm{yr}^{-1}$ (standard deviation of 0.02 metric tha ${ }^{-1} \mathrm{yr}^{-1}$ ). The mean annual rate of soil loss in the watershed will increase significantly to 0.05 metric tha ${ }^{-1} \mathrm{yr}^{-1}$ (standard deviation of 0.07 metric tha ${ }^{-1} \mathrm{yr}^{-1}$ ) should there be complete loss of the existing vegetation cover. This value, 0.05 metric tha ${ }^{-1} \mathrm{yr}^{-1}$ (standard deviation of 0.07 metric tha ${ }^{-1} \mathrm{yr}^{-1}$ ), can also be interpreted as the maximum potential reduction in soil loss (service capacity) that can be produced by the existing vegetation cover. Under existing vegetation cover and management conditions, however, the actual reduction in soil loss (service flow) was recorded at a watershed-wide mean annual value of 0.04 metric tha ${ }^{-1} \mathrm{yr}^{-1}$ (standard deviation of 0.07 metric tha ${ }^{-1} \mathrm{yr}^{-1}$ ). For both service capacity and service flow, only about $0.04 \%$ of the total area of the watershed recorded mean annual values greater than 1 metric tha ${ }^{-1} \mathrm{yr}^{-1}$. These areas had the steepest slopes, indicating the importance of vegetation cover in soil erosion control in these areas. In forested areas, service flow was equal to service capacity, indicating that overall there was no net soil loss from forested areas.

\subsection{Biophysical ecosystem accounts}

The service capacity (Table 5) and service flow (Table 6) ecosystem accounting tables show the distribution of hydrological ecosystem services across the 11 SEAUs for the most current year of simulation, 2012. The total annual values of service capacity correlated with the spatial extent of an SEAU. Larger SEAUs recorded higher values than smaller SEAUs. However, the mean values for service capacity varied depending on the biophysical environment of an SEAU. For example, whereas the Beterou-Ouest SEAU is the largest, the highest mean service capacity of groundwater supply was recorded in the Sarmanga and Terou-Igbomakoro SEAUs. This signifies that the rate of groundwater recharge is highest in the Sarmanga and Terou-Igbomakoro SEAUs. The service flow table reveals that the ecohydrological conditions required for denitrification (water purification) do not occur in the Aguimo, Terou-Igbomakoro, Terou-Wanou, and Wewe SEAUs. However, a total of $77000 \mathrm{~m}^{3}$ of groundwater was extracted in the Terou-Igbomakoro and Wewe SEAUs in 2012. In the Aguimo and Terou-Wanou SEAUs, there is currently no groundwater extraction. For crop water supply, the tables also show the total area of land currently under crop cultivation in each SEAU. Upland agricultural areas provide over $99 \%$ of total cropland area. The SEAUs with the largest upland agricultural areas did not necessarily record the highest service flow. For example, the highest service flow was recorded in Sarmanga and Terou-Igbomakoro. This signifies that maize cultivation in these SEAUs is less prone to water stress than in any other SEAU.

Temporal analysis of ecosystem accounts makes it possible to track ecosystem changes and measure the degree of sustainability, degradation or resilience. Decreasing the capacity of ecosystems to sustain human welfare over time is a measure of ecosystem degradation (EC et al., 2013). Figure 9 shows the results of trend analysis statistical tests of service capacities at the SEAU level. Increasing trends were observed in changes in service capacities of water purification, groundwater supply and surface water supply. For groundwater supply, increasing trends were observed in all SEAUs. The results in Fig. 9a are of the five SEAUs with the highest Mann-Kendall statistic. An increasing trend in changes in surface water supply was observed in four SEAUs, whereas an increasing trend in changes in water purification was observed only in the Aval-Sani SEAU. No trend was observed in changes in the service capacity of crop water supply in both upland agricultural fields and inland valleys in any of the SEAUs. No trend was observed either in changes in the service capacity of soil erosion control in any of the SEAUs.

\section{Discussion}

\subsection{Model uncertainties and limitations}

Model results to support decision-making are always associated with a certain degree of uncertainty. Uncertainty in ecohydrological modelling with SWAT may be from input data, model algorithms, model calibration and validation (parameter non-uniqueness) (Abbaspour et al., 2008). The major input uncertainty in our study was a result of resampling of spatial data from fine spatial resolutions to relatively coarse spatial resolutions in order to increase operational feasibility and computational efficiency of the grid-based SWAT Landscape model. We resampled land use/land cover data, a DEM and a soil map to a spatial resolution of $500 \mathrm{~m} \times 500 \mathrm{~m}$. Even though the spatial rigour of ecosystem accounting requires that modelling approaches that maintain adequate landscape spatial heterogeneity are more suitable, decisions on the 


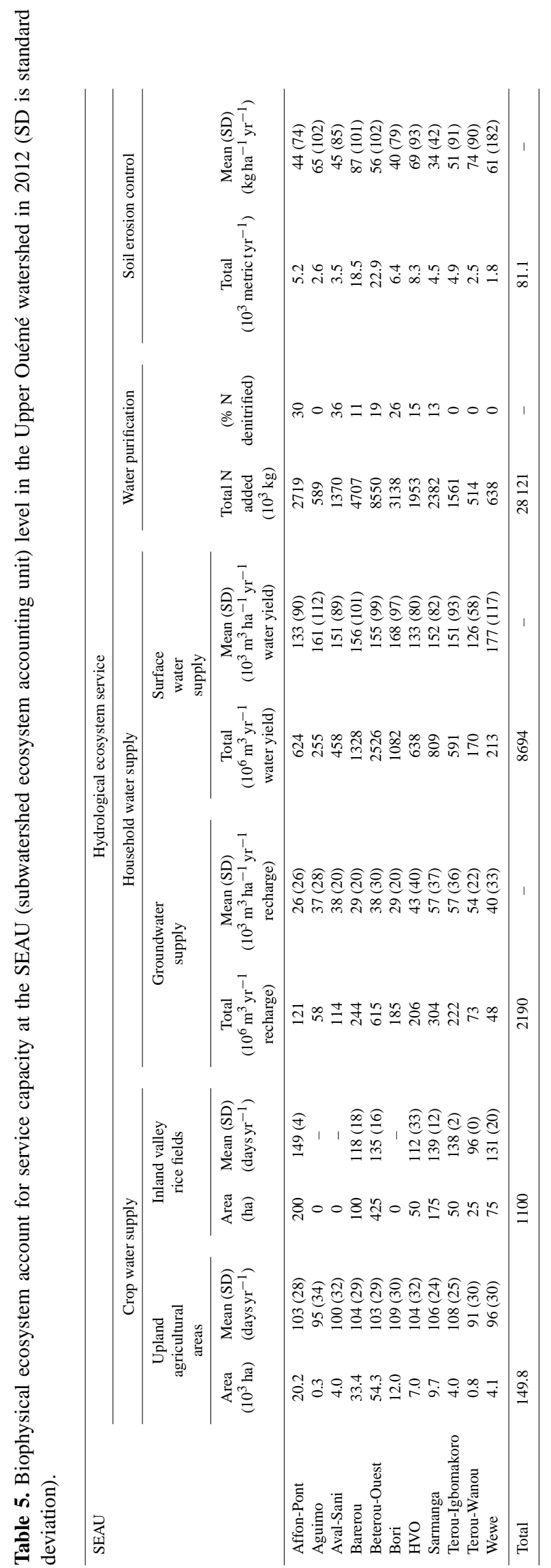




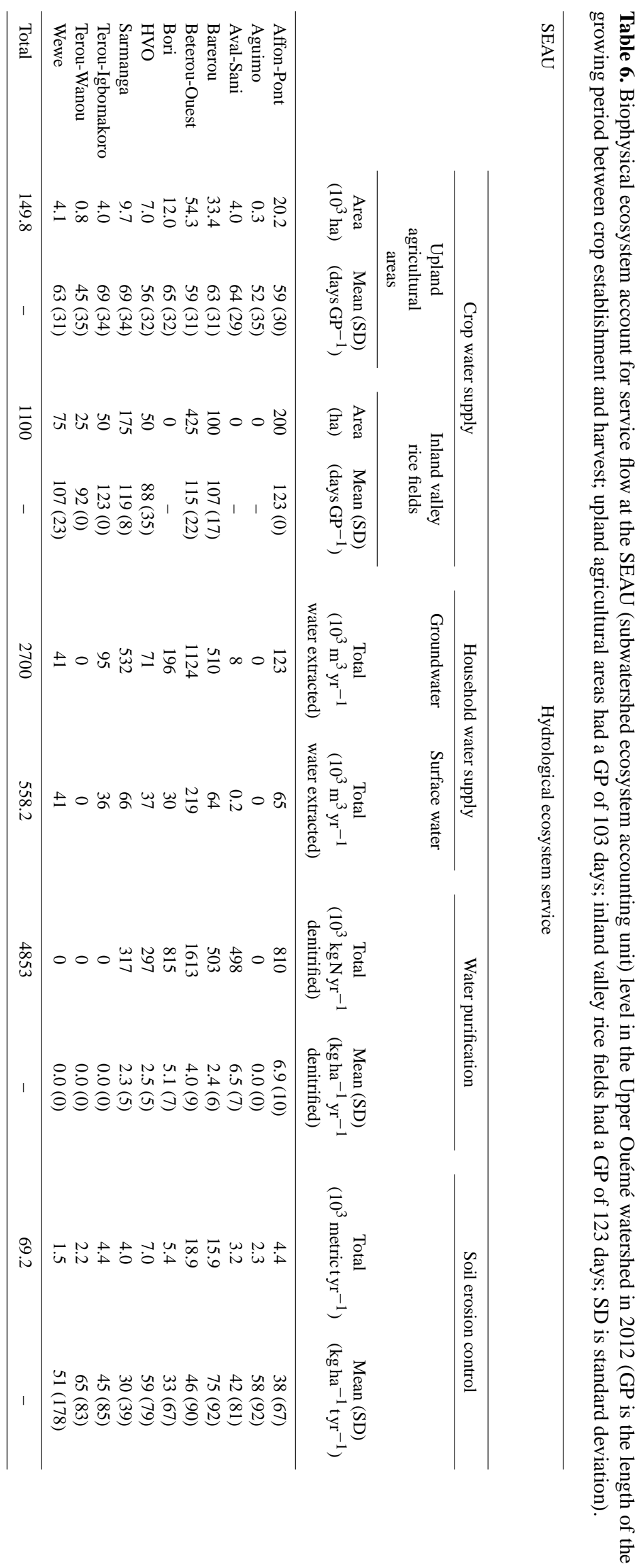



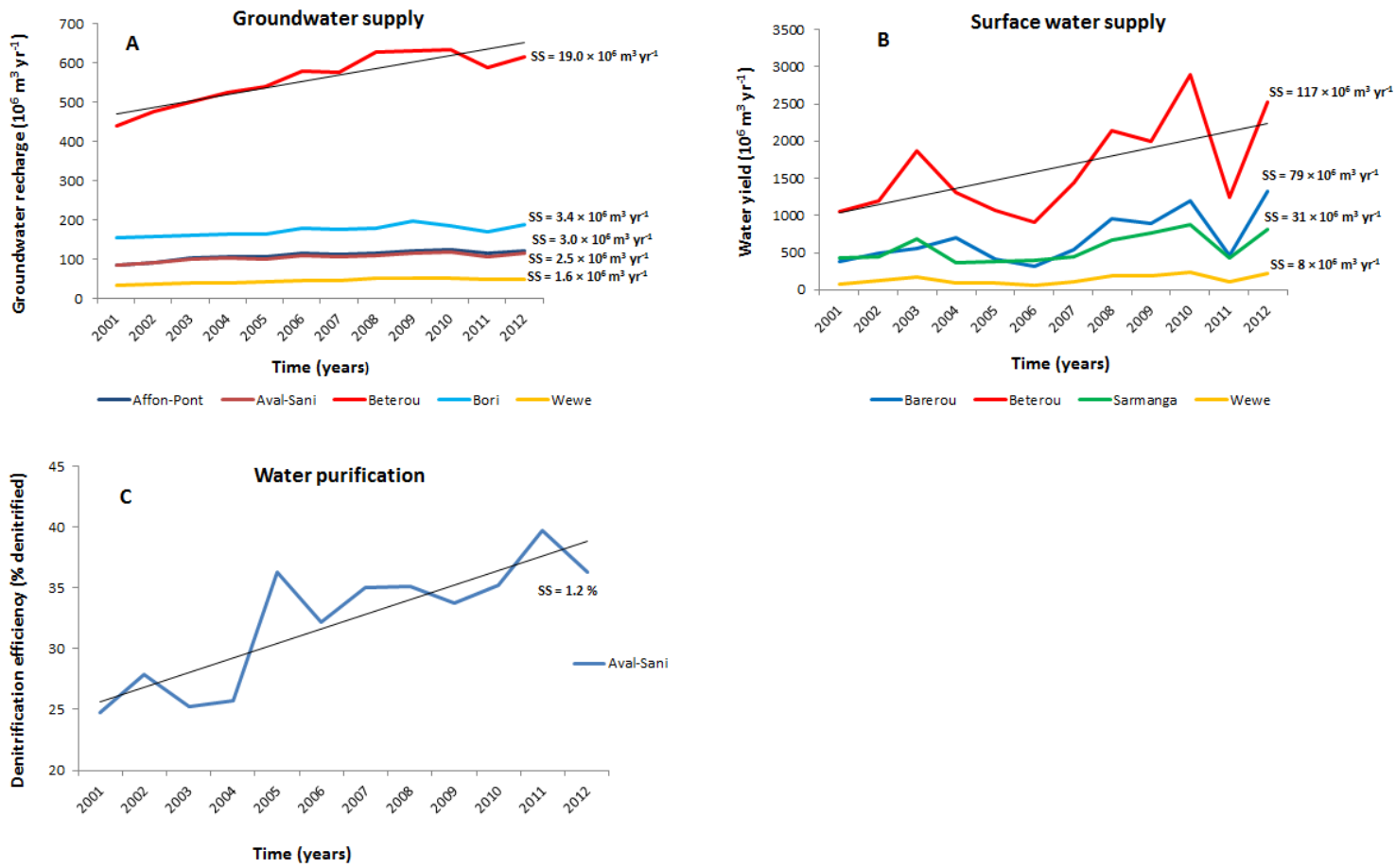

Figure 9. Trends in the service capacity of hydrological ecosystem services at the SEAU level in the Upper Ouémé watershed (SS is Sen's slope estimator, which is a measure of the magnitude of change of a trend). For each graph, a single trend line is drawn solely to illustrate the direction of a trend.

choice of spatial resolution should be made with model computational efficiency and operational feasibility in mind. For the SWAT model (and SWAT Landscape model), increasing spatial detail results in a considerable increase in computing time irrespective of the spatial discretization scheme employed (e.g. Arnold et al., 2010; Notter et al., 2012). In our case-study area, over 1400000 grid cells are generated at 1 ha resolution requiring over 2 days for each simulated year on $2.6 \mathrm{Ghz}$ and $8 \mathrm{~GB}$ RAM. Computer storage capacity for the huge data outputs generated may also not be readily available. We acknowledge that in many regions of the world, high-resolution spatial input data may not be available at large spatial scales. However, for the grid-based set-up of the SWAT Landscape model, where such high-resolution spatial data are available, it may be necessary to compromise spatial explicitness to achieve operational feasibility. This introduces a certain amount of uncertainty with regards to spatial variation in ecohydrological processes; therefore, such decisions should be made taking into consideration the degree of spatial heterogeneity of landscape features. The need to compromise spatial detail for operational feasibility may limit the applicability of this model configuration for larger watersheds.

For larger watersheds, it is also extremely difficult to obtain spatially and temporally correct representations of the underlying ecohydrological processes and interactions. To achieve this, there is a need for multi-site calibration at dif- ferent spatial scales with a sufficient length of time series of data to capture high and low flow years, annual, seasonal and monthly variations (Santhi et al., 2008). In our study, the model underestimated streamflow (especially peak flow) at some monitoring stations, whereas at other stations it overestimated streamflow. These biases in streamflow estimation lead to error propagation in the other components of the water balance such as soil moisture and actual evapotranspiration. Whereas the use of 11 years of daily streamflow data from 11 monitoring stations in the Upper Ouémé watershed reduces the uncertainties of modelled results, data for calibration and validation of sediment and nitrogen loads may not have been sufficient to enable the model to more accurately represent sediment and nitrogen transport processes. In evaluating model performance of sediment and nitrogen transport processes, we used only 2 years of data from a single monitoring station. Without multi-site calibration and validation, there remain large uncertainties in modelled results of sediment and transport processes at different spatial scales. In addition, without long-term temporal validation, there remain large uncertainties in the ability of the model to capture annual variability in these transport processes. Even with sufficient length of time series of multi-site data for calibration and validation, the problem of parameter non-uniqueness inherent in complex watershed models such as the SWAT model also introduces a degree of uncertainty in modelled results. Parameter non-uniqueness refers to the 
reproduction of similar observed ecohydrological signals by different input parameter sets. Therefore, even for so-called calibrated and validated SWAT models, there is always a degree of uncertainty introduced by parameter non-uniqueness. To reduce error propagation, non-uniqueness and consequently reduce parameter uncertainty requires the use of comprehensive data on different fluxes, loads and ecohydrological processes such as crop yield, soil moisture, groundwater level and evapotranspiration (Abbaspour et al., 2008) that are most of the time not readily available.

For this study, we used soil denitrification as an indicator of water purification service. Quantifying denitrification at watershed and subwatershed scales requires the use of models such as SWAT. It involves the simulation of a complex set of processes controlling denitrification that can broadly be classified as the prerequisite environmental/ecohydrological conditions, and microbial processes and dynamics. The SWAT model, however, provides only simplified representations of the complex set of processes controlling denitrification, and modelled estimates of denitrification rates remain highly uncertain (Boyer et al., 2006). The model only simulates the environmental/ecohydrological conditions and does not explicitly simulate microbial processes and dynamics. There is, therefore, an inherent assumption of spatial homogeneity with regards to denitrifier community species composition, quantities and activities across all land use types. Kramer et al. (2006) reported that specific land use and management types (such as organic, integrated and conventional agriculture) enhance or inhibit soil denitrifier activities affecting the rate of denitrification. In the SWAT model, however, spatial variability in denitrification is determined mainly by spatial variability in ecohydrological and abiotic controlling factors.

\subsection{Lessons for ecosystem accounting}

In ecosystem accounting, detailed and accurate land cover and land use data are important. Apart from their use as inputs in modelling ecosystem services, land cover classes are also used as ecosystem accounting units based on which ecosystem services are aggregated (Remme et al., 2014; Schröter et al., 2014). A single lumped land cover class for agricultural areas or croplands (be it as model input data or ecosystem accounting units) may be suitable when modelling and accounting for other ecosystem services (e.g. Remme et al., 2014; Schröter et al., 2014). However, when modelling and accounting for crop water supply, land cover and land use data with detailed and spatially disaggregated information on the types of crops grown in agricultural areas are needed. This is because different crops have different water requirements (Allen et al., 1998). In rainfed agricultural systems, crop water supply is the major limitation to crop production and is the main factor responsible for low yields in the seasonally dry and semiarid tropics and subtropics (Shaxson and Barber, 2003). However, in many of these regions, land cover and land use data with this level of detail are currently not available. Obtaining such information is complicated by the small plot sizes and cropping patterns varying from year to year. Our study area was no exception. Despite these constraints, the lack of detailed data reduces the accuracy and reliability of modelled results of service flow of crop water supply. In our study area, this limitation resulted in the simulation of only a single crop type in upland agricultural areas. Therefore, the results for service flow of crop water supply should be interpreted in the context of the crop simulated. However, because methodologies such as Allen et al. (1998) have been used extensively to compute the water requirements of various crops, our approach serves as a reference or baseline from which the service flow of crop water supply of a spatial unit could be estimated if a crop other than maize is grown.

A key feature of ecosystem accounting is the distinction between service capacity and service flow. The empirical distinction and separate spatial characterization of service capacity and service flow is essential in understanding the dynamics of service provision and in planning and devising sustainable management options. The distinction is also important for subsequent monetary valuation. Service capacity and service flow should be based on measurable indicators that have policy and management relevance. Indicators must also be able to represent cause-effect relations. For hydrological ecosystem services, selecting single indicators of service capacity that meet the above requirements and that sufficiently reflect ecosystem condition and their potential to provide service flows is difficult. This is because of the non-linear complex interactions among several ecohydrological processes that each relies on a suite of ecosystem components (van Oudenhoven et al., 2012; Villamagna et al., 2013). In this study, the service capacity indicators of crop water supply and household water supply meet the above requirements. For example, Ennaanay (2006) and Yan et al. (2013) reported that changes in land use and other ecosystem components alter the hydrological cycle, affecting patterns of evapotranspiration, infiltration, water retention, groundwater recharge and water yield. However, for services such as water purification and soil erosion control, the capacity indicators presented in this study are derived indicators and not actual physical processes. Such indicators do not convey information regarding key physical processes and therefore may not have management relevance. In such cases, a key question that arises is whether the underlying ecosystem components and processes should be weighted and aggregated to produce one composite indicator for service capacity (Edens and Hein, 2013). For example, soil erosion control is a function of surface runoff, slope, soil erodibility, cover and management factors, and support practice factors. Weighing and aggregation of ecosystem components and processes to establish a composite indicator for service capacity, however, is not straightforward and is challenging (Weber, 2007; Stoneham et al., 2012). 


\subsection{Implications for watershed and ecosystem management}

Three of the key issues critical for watershed management and land use planning in an agricultural watershed such as the Upper Ouémé are nitrate leaching, non-point source pollution and alteration in streamflow regime. Nitrate leaching contaminates groundwater resources (Jarvis, 2000; Jahangir et al., 2012). Agricultural non-point source pollution leads to pollution of river networks (Agnew et al., 2006). Alteration of streamflow regime affects riverine ecological integrity and downstream water availability (Carlisle et al., 2011). Ecosystem accounting and spatial characterization of hydrological ecosystem service capacity and flow provide relevant information to help address these issues in policy-making. Such analyses can reveal high-risk areas (i.e. areas that would be affected by changes or continued trends in watershed ecohydrology) or high service production areas (i.e. areas that are crucial for maintaining water flow downstream). For example, our analyses reveal areas where the ecohydrological conditions required for denitrification do not occur but where there is currently groundwater extraction. These areas are high-risk areas of groundwater contamination from nitrate leaching. More crucially, there is currently crop cultivation in some of these areas. Agricultural intensification in these areas, therefore, will result in higher nitrate leaching and contamination of groundwater resources.

Furthermore, the grid-based set-up of the SWAT Landscape model enabled us to identify HSAs at a finer spatial resolution. Characterization of the spatiotemporal dynamics of HSAs is essential in controlling non-point source pollution and in maintaining streamflow regime. Hydrologically sensitive areas have a significant impact on key ecohydrological processes affecting interaction and transport of water, sediment, nutrients and pollutants. They also provide key landscape controls on riverine ecosystem integrity including aquatic flora and fauna and downstream water availability and quality. Agricultural intensification in HSAs has a higher potential for generating agricultural non-point source pollution (Agnew et al., 2006). Land use change in these areas can have a more significant impact on the streamflow regime. Such analyses can form the basis for establishing payment for ecosystem services (PES) schemes (Pagiola and Platais, 2007; Turpie et al., 2008). Watershed PES provides financial support to ecosystem management in high service production areas that are of particular relevance downstream (Lopa et al., 2012; Lu and He, 2014). We acknowledge that detailed ecohydrological modelling is only one of the considerations in establishing a watershed PES. Other considerations include transaction costs and the ability to pay of downstream water users. However, ecohydrological modelling can be used to support watershed PES schemes by providing a tool for upstream water managers to monitor the provision of hydrological ecosystem services or by identifying high ser- vice production areas that are potentially relevant for a new PES.

\section{Conclusion}

There are various components involved in ecosystem service delivery that need to be measured in order to better understand the full dynamics of service provision and to devise sustainable management options. Key amongst these components are service capacity and service flow. Empirical distinction of the service capacity and service flow of ecosystem services is a distinguishing feature of ecosystem accounting and is the basis for monetary accounting. In the casestudy area, we have shown that despite the non-linear complex interactions among several ecohydrological processes, it is empirically feasible to distinguish between service capacity and service flow of hydrological ecosystem services. This requires appropriate decisions regarding physical and mathematical representation of ecohydrological processes, spatial heterogeneity of ecosystems, temporal resolution, and required model accuracy. The service flows we modelled are the contributions in time and space of ecosystems to productive and consumptive human activities leading to human benefits, whereas the service capacities we modelled reflect ecosystem condition and extent at a point in time, and the resulting potential to provide service flows. We demonstrated our approach by using a SWAT model, which has been configured with a grid-based landscape discretization and further enhanced to simulate water flow across the discretized landscape units, to map and quantify four hydrological ecosystem services vital to food and water security in the Upper Ouémé watershed in Benin. We set up ecosystem accounting tables for both service capacity and service flow and analysed trends in service capacities. For each hydrological ecosystem service, we were able to identify subwatershed ecosystem accounting units (SEAUs) where either service capacity or service flow is concentrated. We were also able to identify trends in changes in service capacity of hydrological ecosystem services for some SEAUs. Our approach can be extended and applied to other watersheds because it is based on the SWAT model, which has been tested extensively in different watersheds and landscapes. Our analyses show that integrating hydrological ecosystem services into an ecosystem accounting framework provides relevant information on watershed ecosystems and hydrological ecosystem services at appropriate scales suitable for decision-making.

Author contributions. C. Duku, L. Hein and S. J. Zwart conceived and designed the study; $\mathrm{H}$. Rathjens developed the grid-based model code; C. Duku performed the simulations and analyses; C. Duku and L. Hein prepared the manuscript with contributions from S. J. Zwart and H. Rathjens. 
Acknowledgements. This research was conducted at Wageningen University as part of the "Realizing the potential of inland valley lowlands in sub-Saharan Africa while maintaining their environmental services" project (RAP-IV). The project is implemented by the Africa Rice Center and its national partners and is funded by the European Commission through the International Fund for Agricultural Development (IFAD). We thank the IMPETUS project in Benin for making data available for this research through their public geoportal. We are grateful to Christophe Peugeot and the AMMA-CATCH regional observing system in Benin for providing us precipitation and streamflow data. Finally, we thank Dr. Aymar Bossa and Professor Bernd Diekkrüger for providing us sediment and nitrogen data for model calibration.

Edited by: E. Zehe

\section{References}

Abbaspour, K., Yang, J., Reichert, P., Vejdani, M., Haghighat, S., and Srinivasan, R.: SWAT-CUP, SWAT Calibration and Uncertainty Programs, Swiss Federal Institute of Aquatic Science and Technology (EAWAG), Zurich, Switzerland, 2008.

Agnew, L. J., Lyon, S. W., Gerard-Marchant, P., Collins, V. B., Lembo, A. J., Steenhuis, T. S., and Walter, M. T.: Identifying hydrologically sensitive areas: bridging the gap between science and application, J. Environ. Manage., 78, 63-76, doi:10.1016/j.jenvman.2005.04.021, 2006.

Allen, R. G., Pereira, S. L., Raes, D., and Smith, M.: Irrigation and Drainage Paper 56, FAO, Rome, Italy, 1998.

AMMA-CATCH Database, available at: http://bd.amma-catch.org/ amma-catch2/main.jsf (last access: 28 May 2014), 2014.

Arnold, J. G., Srinivasan, R., Muttiah, R. S., and Williams, J. R.: Large area hydrologic modeling and assessment - Part I: Model development, J. Am. Water Resour. As., 34, 73-89, 1998.

Arnold, J. G., Allen, P. M., Volk, M., Williams, J. R., and Bosch, D. D.: Assessment of different representations of spatial variability on swat model performance, T. ASABE, 53, 1433-1443, 2010.

Arnold, J. G., Kiniry, J. R., Srinivasan, R., Williams, J. R., Haney, E. B., and Neitsch, S. L.: Soil Water and Assessment Tool Input/Output Documentation Version 2012, Texas Water Resources Institute, College Station, Texas, USA, 2013.

Bosch, D. D., Arnold, J. G., Volk, M., and Allen, P. M.: Simulation of a low-gradient coastal plain watershed using the swat landscape model, T. ASABE, 53, 1445-1456, 2010.

Bossa, A. Y., Diekkrüger, B., Giertz, S., Steup, G., Sintondji, L. O., Agbossou, E. K., and Hiepe, C.: Modeling the effects of crop patterns and management scenarios on $\mathrm{N}$ and $\mathrm{P}$ loads to surface water and groundwater in a semi-humid catchment (West Africa), Agr. Water Manage., 115, 20-37, doi:10.1016/j.agwat.2012.08.011, 2012.

Boyd, J. and Banzhaf, S.: What are ecosystem services? The need for standardized environmental accounting units, Ecol. Econ., 63, 616-626, doi:10.1016/j.ecolecon.2007.01.002, 2007.

Boyer, E. W., Alexander, R. B., Parton, W. J., Li, C. S., ButterbachBahl, K., Donner, S. D., Skaggs, R. W., and Del Gross, S. J.: Modeling denitrification in terrestrial and aquatic ecosystems at regional scales, Ecol. Appl., 16, 2123-2142, doi:10.1890/10510761(2006)016[2123:Mditaa]2.0.Co;2, 2006.

Brauman, K. A., Daily, G. C., Duarte, T. K., and Mooney, H. A.: The nature and value of ecosystem services: An overview highlighting hydrologic services, Ann. Rev. Env. Resour., 32, 67-98, doi:10.1146/annurev.energy.32.031306.102758, 2007.

Carlisle, D. M., Wolock, D. M., and Meador, M. R.: Alteration of streamflow magnitudes and potential ecological consequences: a multiregional assessment, Front. Ecol. Environ., 9, 264-270, doi:10.1890/100053, 2011.

EC, OECD (Organisation for Economic Co-operation and Development), UN (United Nations), and World Bank: System of Environmental-Economic Accounting 2012, Experimental Ecosystem Accounting, New York, USA, 2013.

Edens, B. and Hein, L.: Towards a consistent approach for ecosystem accounting, Ecol. Econ., 90, 41-52, doi:10.1016/j.ecolecon.2013.03.003, 2013.

Ennaanay, D.: Impacts of Land Use Changes on the Hydrologic Regime in the Minnesota River Basin, Major: Water Resources Science, 2006, University of Minnesota, USA, 2006.

ESRI: ArcGIS version 10.1, Redlands, California, USA, 2012.

FAO: Methodology and results for Africa, in: Report on the agroecological zones project, vol. 1., Food and Agriculture Organization, Rome, Italy, 1978.

FAO: Guidelines: land evaluation of rainfed agriculture, Soils Bulletin, 52, Food and Agriculture Organization, Rome, Italy, 1983.

Fisher, B., Turner, R. K., and Morling, P.: Defining and classifying ecosystem services for decision making, Ecol. Econ., 68, 643653, doi:10.1016/j.ecolecon.2008.09.014, 2009.

Garbrecht, J. and Martz, L.: Topaz User Manual: Version 3.1, Technical Report. Grazinglands Research Laboratory, USDA, Agricultural Research Service, El Reno, Oklahoma, 2000.

Gassman, P. W., Reyes, M. R., Green, C. H., and Arnold, J. G.: The soil and water assessment tool: historical development, applications, and future research directions, T. ASABE, 50, 1211-1250, 2007.

Giertz, S., Steup, G., and Schonbrodt, S.: Use and constraints on the use of inland valley ecosystems in central Benin: results from an inland valley survey, Erdkunde, 66, 239-253, doi:10.3112/erdkunde.2012.03.04, 2012.

Gupta, H. V., Sorooshian, S., and Yapo, P. O.: Status of automatic calibration for hydrologic models: Comparison with multilevel expert calibration, J. Hydrol. Eng., 4, 135-143, 1999.

Guswa, A. J., Brauman, K. A., Brown, C., Hamel, P., Keeler, B. L., and Sayre, S. S.: Ecosystem services: Challenges and opportunities for hydrologic modeling to support decision making, Water Resour. Res., 50, 4535-4544, doi:10.1002/2014wr015497, 2014.

Hadjer, K., Klein, T., and Schopp, M.: Water consumption embedded in its social context, north-western Benin, Phys. Chem. Earth, 30, 357-364, doi:10.1016/j.pce.2005.06.014, 2005.

Hargreaves, G. L., Hargreaves, G. H., and Riley, J. P.: Agricultural benefits for Senegal river basin, J. Irrig. Drain E-ASCE, 111, 113-124, 1985.

INSAE: Troisième Recensement Général de la Population et de l'Habitation, Cotonou, Benin, 2003.

IWMI: Water for Food Water for Life: a Comprehensive Assessmesnt of Water Management in Agriculture, Earthscan, London, UK, 2007. 
Jahangir, M. M. R., Khalil, M. I., Johnston, P., Cardenas, L. M., Hatch, D. J., Butler, M., Barrett, M., O'flaherty, V., and Richards, K. G.: Denitrification potential in subsoils: a mechanism to reduce nitrate leaching to groundwater, Agr. Ecosyst. Environ., 147, 13-23, doi:10.1016/j.agee.2011.04.015, 2012.

Jarvis, S. C.: Progress in studies of nitrate leaching from grassland soils, Soil Use Manage., 16, 152-156, 2000.

Jones, P. and Harris, I.: CRU TS3.21: Climatic Research Unit (CRU) Time-Series (TS) Version 3.21 of High Resolution Gridded Data of Month-by-month Variation in Climate (January 1901-December 2012), University of East Anglia Climatic Research Unit (CRU), NCAS British Atmospheric Data Centre, doi:10.5285/D0E1585D-3417-485F-87AE4FCECF10A992, 2013.

Judex, M. and Thamm, H. P.: IMPETUS Atlas Benin. Research Results 2000-2007, 3rd Edn., Department of Geography, University of Bonn, Germany, 2008.

Kramer, S. B., Reganold, J. P., Glover, J. D., Bohannan, B. J. M., and Mooney, H. A.: Reduced nitrate leaching and enhanced denitrifier activity and efficiency in organically fertilized soils, P. Natl. Acad. Sci. USA, 103, 4522-4527, 2006.

Le Maitre, D. C., Milton, S. J., Jarmain, C., Colvin, C. A., Saayman, I., and Vlok, J. H. J.: Linking ecosystem services and water resources: landscape-scale hydrology of the Little Karoo, Front. Ecol. Environ., 5, 261-270, 2007.

Leh, M. D. K., Matlock, M. D., Cummings, E. C., and Nalley, L. L.: Quantifying and mapping multiple ecosystem services change in West Africa, Agr. Ecosyst. Environ., 165, 6-18, doi:10.1016/j.agee.2012.12.001, 2013.

Liquete, C., Maes, J., La Notte, A., and Bidoglio, G.: Securing water as a resource for society: an ecosystem services perspective, Ecohydrology and Hydrobiology, 11, 247-259, doi:10.2478/v10104011-0044-1, 2011.

Liu, T., Merrill, N. H., Gold, A. J., Kellogg, D. Q., and Uchida, E.: Modeling the production of multiple ecosystem services from agricultural and forest landscapes in Rhode Island, Agricultural and Resource Economics Review, 42, 251-274, 2013.

Lopa, D., Mwanyoka, I., Jambiya, G., Massoud, T., Harrison, P., Ellis-Jones, M., Blomley, T., Leimona, B., van Noordwijk, M., and Burgess, N. D.: Towards operational payments for water ecosystem services in Tanzania: a case study from the Uluguru Mountains, Oryx, 46, 34-44, doi:10.1017/S0030605311001335, 2012.

Lu, Y. and He, T.: Assessing the effects of regional payment for watershed services program on water quality using an intervention analysis model, Sci. Total Environ., 493, 1056-1064, doi:10.1016/j.scitotenv.2014.06.096, 2014.

Maes, J., Egoh, B., Willemen, L., Liquete, C., Vihervaara, P., Schägner, J. P., Grizzetti, B., Drakou, E. G., Notte, A. L., Zulian, G., Bouraoui, F., Luisa Paracchini, M., Braat, L., and Bidoglio, G.: Mapping ecosystem services for policy support and decision making in the European Union, Ecosystem Services, 1, 31-39, doi:10.1016/j.ecoser.2012.06.004, 2012.

Maler, K. G., Aniyar, S., and Jansson, A.: Accounting for ecosystem services as a way to understand the requirements for sustainable development, P. Natl. Acad. Sci. USA, 105, 9501-9506, doi:10.1073/pnas.0708856105, 2008.

Martínez-Harms, M. J. and Balvanera, P.: Methods for mapping ecosystem service supply: a review, International Journal of Bio- diversity Science, Ecosystem Services and Management, 8, 1725, doi:10.1080/21513732.2012.663792, 2012.

Moriasi, D. N., Arnold, J. G., Van Liew, M. W., Bingner, R. L., Harmel, R. D., and Veith, T. L.: Model evaluation guidelines for systematic quantification of accuracy in watershed simulations, T. ASABE, 50, 885-900, 2007.

Naidoo, R., Balmford, A., Costanza, R., Fisher, B., Green, R. E., Lehner, B., Malcolm, T. R., and Ricketts, T. H.: Global mapping of ecosystem services and conservation priorities, P. Natl. Acad. Sci. USA, 105, 9495-9500, doi:10.1073/pnas.0707823105, 2008.

Nash, J. E. and Sutcliffe, J. V.: River flow forecasting through conceptual models: Part 1. A discussion of principles, J. Hydrol., 10, 282-290, 1970.

Neitsch, S. L., Arnold, J. G., Kiniry, J. R., and Williams, J. R.: Soil and Water Assessment Tool, Theoretical Documentation, Grassland, Soil and Water Resources Laboratory, Temple, TX, USA, 2009.

Notter, B., Hurni, H., Wiesmann, U., and Abbaspour, K. C.: Modelling water provision as an ecosystem service in a large East African river basin, Hydrol. Earth Syst. Sci., 16, 69-86, doi:10.5194/hess-16-69-2012, 2012.

Obst, C., Edens, B., and Hein, L.: Ecosystem services: accounting standards, Science, 342, p. 420 , doi:10.1126/science.342.6157.420-a, 2013.

Orekan, V. O. A.: Implementation of the local land-use and land-cover change model CLUE-s for central Benin by using socio-economic and remote sensing data, $\mathrm{PhD}$ thesis, Mathematisch-Naturwissenschaftlichen Fakultät, Rheinischen Friedrich-Wilhelms-Universität Bonn, Bonn, Germany, 2007.

Pagiola, S. and Platais, G.: Payments for Environmental Services: from Theory to Practice, World Bank, Washington, 2007.

Pattanayak, S. K. and Kramer, R. A.: Worth of watersheds: a producer surplus approach for valuing drought mitigation in Eastern Indonesia, Environ. Dev. Econ., 6, 123-146, doi:10.1017/S1355770x01000079, 2001.

Rathjens, H. and Oppelt, N.: SWATgrid: an interface for setting up SWAT in a grid-based discretization scheme, Comput. Geosci.UK, 45, 161-167, doi:10.1016/j.cageo.2011.11.004, 2012.

Rathjens, H., Oppelt, N., Bosch, D. D., Arnold, J. G., and Volk, M.: Development of a grid-based version of the SWAT landscape model, Hydrol. Process., 29, 900-914, doi:10.1002/hyp.10197, 2014.

Remme, R. P., Schröter, M., and Hein, L.: Developing spatial biophysical accounting for multiple ecosystem services, Ecosystem Services, 10, 6-18, 2014.

Rodenburg, J., Zwart, S. J., Kiepe, P., Narteh, L. T., Dogbe, W., and Wopereis, M. C. S.: Sustainable rice production in African inland valleys: seizing regional potentials through local approaches, Agr. Syst., 123, 1-11, doi:10.1016/j.agsy.2013.09.004, 2014

Santhi, C., Kannan, N., Arnold, J. G., and Di Luzio, M.: Spatial calibration and temporal validation of flow for regional scale hydrologic modeling, J. Am. Water Resour. As., 44, 829-846, doi:10.1111/j.1752-1688.2008.00207.x, 2008.

Schröter, M., Barton, D. N., Remme, R. P., and Hein, L.: Accounting for capacity and flow of ecosystem services: a conceptual model and a case study for Telemark, Norway, Ecol. Indic., 36, 539-551, doi:10.1016/j.ecolind.2013.09.018, 2014. 
Seppelt, R., Dormann, C. F., Eppink, F. V., Lautenbach, S., and Schmidt, S.: A quantitative review of ecosystem service studies: approaches, shortcomings and the road ahead, J. Appl. Ecol., 48, 630-636, doi:10.1111/j.1365-2664.2010.01952.x, 2011.

Shaxson, F. and Barber, R.: Optimizing soil moisture for plant production. The significance of soil porosity, FAO Soils Bulletin, FAO Soils Bulletin, 79, Rome, Italy, 2003.

Stoneham, G., O'Keefe, A., Eigenraam, M., and Bain, D.: Creating physical environmental asset accounts from markets for ecosystem conservation, Ecol. Econ., 82, 114-122, doi:10.1016/j.ecolecon.2012.06.017, 2012.

TEEB: The economics of ecosystems and biodiversity. Mainstreaming the economics of nature. A synthesis of the approach, conclusions and recommendations of TEEB, available at: www. teebweb.org, last access: 4 September 2014, 2010.

Terrado, M., Acuna, V., Ennaanay, D., Tallis, H., and Sabater, S.: Impact of climate extremes on hydrological ecosystem services in a heavily humanized Mediterranean basin, Ecol. Indic., 37, 199-209, doi:10.1016/j.ecolind.2013.01.016, 2014.

Tilman, D., Cassman, K. G., Matson, P. A., Naylor, R., and Polasky, S.: Agricultural sustainability and intensive production practices, Nature, 418, 671-677, doi:10.1038/nature01014, 2002.

Turpie, J. K., Marais, C., and Blignaut, J. N.: The working for water programme: evolution of a payments for ecosystem services mechanism that addresses both poverty and ecosystem service delivery in South Africa, Ecol. Econ., 65, 788-798, doi:10.1016/j.ecolecon.2007.12.024, 2008.

UN, European Commission, International Monetary Fund, Organisation for Economic Co-operation and Development, and World Bank: System of National Accounts 2008, New York, 2009.

van Oudenhoven, A. P. E., Petz, K., Alkemade, R., Hein, L., and de Groot, R. S.: Framework for systematic indicator selection to assess effects of land management on ecosystem services, Ecol. Indic., 21, 110-122, doi:10.1016/j.ecolind.2012.01.012, 2012.

Vigerstol, K. L. and Aukema, J. E.: A comparison of tools for modeling freshwater ecosystem services, J. Environ. Manage., 92, 2403-2409, doi:10.1016/j.jenvman.2011.06.040, 2011.
Villamagna, A. M., Angermeier, P. L., and Bennett, E. M.: Capacity, pressure, demand, and flow: a conceptual framework for analyzing ecosystem service provision and delivery, Ecol. Complex., 15, 114-121, doi:10.1016/j.ecocom.2013.07.004, 2013.

Volk, M., Arnold, J. G., Bosch, D. D., Allen, P. M., and Green, C. H.: Watershed configuration and simulation of landscape processes with the SWAT model, in: MODSIM 2007 International Congress on Modelling and Simulation, Christchurch, New Zealand, 10 December 2007 through 13 December 2007, edited by: Oxley, L. and Kulasiri, D., Modeling and Simulation Society of Australia and New Zealand, 1383-2389, 2007.

Weber, J. L.: Land and Ecosystem Accounts in the SEEA Revision, paper presented to the 13th meeting of the London Group, available at: http://unstats.un.org/unsd/envaccounting/londongroup/ meeting13/LG13_25a.pdf, last access: 4 September 2014, 2007.

Willaarts, B. A., Volk, M., and Aguilera, P. A.: Assessing the ecosystem services supplied by freshwater flows in Mediterranean agroecosystems, Agr. Water Manage., 105, 21-31, doi:10.1016/j.agwat.2011.12.019, 2012.

Williams, J. R.: Sediment-yield prediction with universal equation using runoff energy factor, in: Present and prospective technology for predicting sediment yield and sources, Proceedings of the Sediment Yield Workshop, USDA Sedimentation Laboratory, Oxford, Mississippi, 28-30 November 1972, U.S. Department of Agriculture, Washington, D.C., 244-252, 1975.

Wolfe, A. H. and Patz, J. A.: Reactive nitrogen and human health: acute and long-term implications, Ambio, 31, 120-125, 2002.

Yan, B., Fang, N. F., Zhang, P. C., and Shi, Z. H.: Impacts of land use change on watershed streamflow and sediment yield: an assessment using hydrologic modelling and partial least squares regression, J. Hydrol., 484, 26-37, doi:10.1016/j.jhydrol.2013.01.008, 2013.

Zang, C. F., Liu, J., van der Velde, M., and Kraxner, F.: Assessment of spatial and temporal patterns of green and blue water flows under natural conditions in inland river basins in Northwest China, Hydrol. Earth Syst. Sci., 16, 2859-2870, doi:10.5194/hess-162859-2012, 2012. 